\title{
Premium Copayments and the Trade-off between Wages and Employer-Provided Health Insurance
}

\author{
June 7, 2013 \\ By \\ Darren Lubotsky \\ University of Illinois at Urbana-Champaign \\ lubotsky@illinois.edu \\ Craig A. Olson \\ University of Illinois at Urbana-Champaign \\ caolson@illinois.edu
}

\begin{abstract}
This paper estimates the trade-off between salary and health insurance costs using data on Illinois school teachers between 1991 and 2008 that allow us to address several common empirical challenges in this literature. We find no evidence that changes in teachers' salaries respond to changes in insurance cost, but teachers paid about 17 percent of the cost of individual health insurance and about 46 percent of the cost of their family members' plans through increased premium copayments. Our results indicate that premium increases were not associated with commensurate increases in teachers' valuation of their health insurance plans.
\end{abstract}

\section{JEL Codes: I13, I2, and J32}

We thank Bradley Heim, Robert Kaestner, and seminar participants at Indiana University, the Midwest Health Economics Conference, Purdue University, the Society of Labor Economists Annual Meeting, the University of Illinois, the University of Nevada-Las Vegas, and the University of Tennessee for feedback and suggestions. Any errors are ours. 


\section{Premium Copayments and the Trade-off between Wages and Employer-Provided Health Insurance}

\section{Introduction}

One of the most pressing issues that continues to confront policy-makers, employers and individuals is that the growth in health care costs have exceeded the growth of per capita incomes, wages, and the price of other goods for several decades. In 1960 annual per capita health spending was $\$ 809$ (in 2009 dollars) and by 2009 it had increased to $\$ 7375$, for an average annual growth rate of 4.6 percent (Chernew and Newhouse 2011). Over this same period, inflation-adjusted per capita income increased by 1.8 percent. ${ }^{1}$ This large and persistent growth in health care spending was an important issue in the debate over the Affordable Care Act and is a top concern for employers and workers because the vast majority of the under-65 population who have health insurance coverage receive their coverage as part of an employee compensation package. The growth in health care costs is also central to the long-term prospects for the federal and state government budgets through its effects on the cost of publically-provided insurance and on the costs to provide health insurance to public-sector workers. This paper investigates the incidence of rising health insurance premiums using a unique data set from over 600 public school districts in Illinois that tracks wages, health insurance premiums, and employee premium copayments for public school teachers from 1990-91 through the 2007-2008 school years.

While employer-provided health insurance premiums and total employment costs have been rising steadily over the last half-century, employees' monetary compensation has remained relatively flat. Economists traditionally interpret the disparity in these trends as partially reflecting an implicit (and sometimes explicit) trade-off that employees make between salary, other forms of compensation, and job attributes more generally. As health insurance costs increase, employees are increasingly willing to accept slower wage growth to maintain their health benefits. A long line of

\footnotetext{
${ }^{1}$ Per capita personal income in 1960 was $\$ 14,651$ (in 2009 dollars) and in 2009 was $\$ 35,115$. Data on personal income is from the Bureau of Economic Analysis National Income and Product Accounts. Data on the Consumer Price Index is from the Bureau of Labor Statistics.
} 
empirical research, however, has failed to find clear evidence that health insurance costs are borne by employees, which calls into question the long-standing views most economists hold about the incidence of rising health insurance costs and, more generally, whether the labor market operates as a sorting mechanism based on employer and employee preferences for employer-provided health benefits.

This paper estimates the trade-off between salary and health insurance costs using a unique data source on salary and benefits provided to public school teachers in over 600 schools districts in Illinois between 1991 and 2008. Public school teachers are an interesting and important group to study: there is a widely-held belief that public-sector employees receive higher compensation than what they would earn in the private-sector and much of the disparity is driven by differences in employee benefits. Recent attempts in Wisconsin and Ohio to restrict collective bargaining by public-sector employees were predicated, in part, on the desire to reduce compensation costs in general and employee benefit costs in particular. A similar debate is going on Illinois, where there are policy proposals to reduce the value of pensions for public-sector workers. These debates generally ignore the possibility that salaries and benefits are jointly determined, so attempts to reduce benefit costs will generally put upward pressure on salaries to maintain the same quality workforce.

Illinois public school teachers are also interesting to study because we have an almost ideal dataset to examine the trade-off between salary and benefits and can address some of the empirical limitations that have plagued past work. The salary survey that we use includes information on the premiums for individual and family health insurance plans and the fraction of the premium that is paid by the teacher through a so-called premium copayment (i.e. through regular salary deductions). These premium copayments are important and have not been well-studied in the literature. According to nationally-representative survey data compiled by the Kaiser Family Foundation, 84 percent of workers covered by employer-provided insurance paid a premium copayment for their individual insurance in 2011, up from 76 percent in 2002. 'These premium copayments accounted for 18 percent of the premium for individual coverage in 2011 and 28 percent of the premium for

\footnotetext{
${ }^{2}$ Kaiser Family Foundation and Health Research and Educational Trust (2011). These data refer to privatesector and public-sector employees, excluding employees of the federal government.
} 
family coverage. ${ }^{3}$ Our data on Illinois school district compensation contracts thus allows us to directly measure the correlation between changes in insurance premiums, salaries, and premium copayments.

Economic theory offers a clear prediction about the relationship between wages, health insurance costs, and total compensation. When both employees and firms are willing to substitute insurance (and other benefits) for some of their salary, exogenous changes in the value of benefits will be offset by changes in salary, leaving total compensation unaffected. This is true both in a competitive spot labor market, where the labor market serves as a sorting devise to match workers and firms who share a preferred mix of salary and benefits, as well as in a union-management negotiation, which is the case we study. In union-management contract negotiations, management is concerned about the total compensation an employee receives and how the mix of wages and benefits affects workforce quality; unions will negotiate a compensation level and mix that a majority of members will support. A long line of research, however, has been largely unsuccessful in estimating a meaningful trade-off between health insurance and wages (Currie and Madrian 2000). .

Data problems, as opposed to poor theory, have been the primary reason offered to explain why it has been difficult to empirically measure wage offsets from rising health insurance costs. One frequently cited reason for the lack of empirical support is that typical data sources have poor measures of individual productivity. An OLS regression often finds a positive association between wages and health insurance, which simply reflects the fact that higher skilled workers tend to receive both high wages and more benefits. It is exceedingly difficult to adequately control for individual productivity and remove this omitted variables bias. A second reason is that data on employee

3 The National Compensation Survey conducted by the BLS for 2011 found that among all civilian employees with employer provided health benefits, employees paid for 21 percent of the cost of individual coverage and 33 percent of the cost of family coverage through premium copayments that were deducted from a worker's pay check. See BLS series NBU11500000000000031175 and NBU11500000000000031177 at bls.gov/ncs/. 
premium copayments are not part of many datasets used to study the wage-health insurance tradeoff. Thus, to the extent that adjustments occur though premium copayments, the relationship between gross compensation and the level of health insurance benefits will understate the overall relationship between wages and insurance premiums.

Our analysis indicates that total health insurance costs rose for Illinois teachers at the same rate as they did nationally. We find no evidence that changes in teachers' salaries within a district over time are related to changes in insurance premiums. The absence of an estimated salary offset for teachers does not mean teacher take-home pay did not fall when premiums increased: Rising premium costs were offset by rising teacher premium copayments; teachers paid about 17 cents in higher premium copayments for each dollar increase in the cost of individual health insurance and about a 46 cent premium copayment increase for each dollar increase in the cost of family coverage. Offsets through premium copayments are larger in districts that have longer-tenured (thus older) teachers: a one-year rightward shift in the teacher tenure distribution increases the teacher premium copayment by an additional 3 cents for each dollar increase in premiums. We find no evidence that rising health insurance premiums reduce districts' demand for teachers or that districts substitute less-experienced teachers when health costs rise.

We draw two conclusions from these results. First, cash compensation partially adjusts to rising premium costs, though all of the adjustment comes through premium copayments and not through negotiated salary levels. Second, that the premium offset is significantly larger in districts with an older workforce is consistent with older workers placing a higher value on the health benefits associated with higher premiums.

\section{The Relationships between Health Insurance Premiums, Wages and Employee}

The starting point for understanding how wages and premiums respond to changes in health insurance premiums begins with the model used to explain differences in wages and health insurance premiums across employers at a point in time. Goldstein and Pauly (1976) were the first to develop a formal model of this relationship. They assume workers are perfectly exchangeable in the production process, face the same expected health care costs and differ only in their level of risk aversion. Workers have preferences for take-home salary, $s_{i t}$, and health benefits, $h_{i t}$, and maximize utility $U_{i t}=U\left(s_{i t}, h_{i t}\right.$ (risk aversion)), where take-home salary is the difference between 
the employee's nominal salary, $w_{i t}$, and the employees' health insurance premium copayment or contribution, $c_{i t}$; and the utility of health insurance is solely a function of worker risk aversion. Total labor cost per worker is identical across firms and is equal to the marginal revenue product of a worker, and is also equal to cash compensation plus the cost of health insurance. The budget constraint produces a set of equilibrium salary levels and health insurance premium combinations that trace out a hedonic wage function $s_{i t}=S\left(h_{i t}\right)$, a level of take-home salary for each observed level of health insurance. This equilibrium implies a marginal condition that $-U_{h} / U_{s}=S^{\prime}\left(h_{i t}\right)$ : the employees' marginal rate of substitution between health insurance and salary, which depends on risk aversion, is equal to the marginal change in salary that results from a marginal change in health insurance, i.e. the "price" of health insurance in terms of reduced salary. Differences in worker risk aversion mean that firms offer different combinations of cash compensation and health insurance benefits to match the distribution of worker preferences and each worker is matched to a firm that offers the compensation package that maximizes her utility. This sorting of workers across firms means an employer need offer only one health insurance plan because all workers in the firm have identical risk preferences.

The Goldstein and Pauly model produces the well-known negative trade-off between wages and fringe benefits. There is a distribution of wage-health insurance offerings solely because of different worker preferences. The tradeoff does not require differences across employers in either the costs of offering health insurance or in any benefits health insurance might provide to an employer in attracting or retaining more productive workers. The negative relationship between cash compensation and health insurance premiums continues to hold when the model's assumptions are relaxed and heterogeneity is allowed in worker productivity, expected health care expenditures, the costs and benefits to employers from offering health insurance, and when we move from a competitive spot labor market to a unionized setting.

The trade-off between wages and health insurance is empirically estimated using a hedonic wage regression that expresses an individuals' take-home cash compensation, $s_{i t}$, as a function of the cost of employer-provided health insurance (and possibly other job attributes) (Brown 1980; Rosen 1986). Take home salary is equal to the wage rate, $w_{i t}$, less the employees' contribution to their health insurance premium, $c_{i t}$, or:

$$
s_{i t}=w_{i t}-c_{i t}=\alpha+\beta h_{i t}+\gamma X_{i t}+\varepsilon_{i t},
$$


where $\alpha$ is a constant term, $X_{i t}$, are individual characteristics that are potentially correlated with health insurance that affect worker productivity, and $\varepsilon_{i t}$ is an unobserved error term. The parameter $\beta$ captures the trade-off between health insurance and take-home salary. If $\beta=-1$ then a dollar increase in health insurance costs translates directly into a dollar less of take-home pay and premium increases are fully offset by a decline in cash compensation. Since health insurance is not taxed as income, a dollar-for-dollar tradeoff implies that teachers capture all of the favorable tax treatment of health benefits. If, in response to a dollar increase in premiums, a districts reduces cash compensation by a dollar, total labor costs to the employer remains unchanged but an employee's after-tax income declines by only (1-Marginal Tax Rate). Alternatively, the employer captures all of the tax benefit if the parties agree to reduce take-home pay by 1/(1-Marginal Tax Rate) when premiums increase by a dollar.

Most studies fail to empirically confirm the negative relationship between wages and health insurance premiums, though there are some notable exceptions. ${ }^{4}$ For example, Eberts and Stone (1985) study public school teachers in New York and find that each dollar increase in health insurance costs between 1972 and 1976 was offset by about an 83 cent decrease in salary. Olson (2002) finds a negative effect of employer coverage on wages for married women working full-time using husband's own employer coverage, husband's union status, and husband's firm size as instruments. Baicker and Chandra (2006) find evidence of a fully compensated offset for those covered by employer-provided health insurance using medical malpractice settlement size as an instrument for health insurance costs. Kolstad and Kowalski (2012) study the 2006 Massachusetts health insurance mandates and conclude that wages adjusted to fully offset the cost of employerprovided health insurance. Notably most of these studies estimate a compensating difference between jobs with and without health insurance. By contrast, we focus on how compensation adjusts to year-to-year changes in the cost of health insurance among people who are insured. In

${ }_{4}$ See Currie and Madrian (2000) for a review of the earlier literature. Also see Levy and Feldman (2001), Simon (2001), Lehrer and Pereira (2007), and Royalty (2008). 
addition, none of these studies estimate how premiums affect worker take-home pay through changes in employee premium copayments. ${ }^{5}$

A number of other studies have found a relationship between wages and individual characteristics that correlate with the demand for health care. Gruber (1994) found that working women of child-bearing age with health insurance saw their wages decline when their state required insurance policies issued by insurance companies were required to offer maternity benefits. Sheiner (1999) found a flatter age-earnings profile for workers in markets with high medical care prices. Pauly and Herring (1999) found that predicted medical expenditures have a negative impact on the wages of older workers. Bhattacharya and Bundorf (2009) found a significant wage differential between obese and thinner women for those covered by health insurance, but no differential for those without insurance. While all of these studies are consistent with the predictions from the theory, on the whole, there is very little direct evidence that increases in health insurance premiums are fully offset by a decline in cash compensation .

The most common explanation offered for the lack of empirical support for the model is the presence of unobserved worker productivity that is positively correlated with the cross-sectional variation wages and either health insurance premiums or health insurance coverage. ${ }^{6}$ Indeed, our analysis of nationally-representative, cross-sectional data from the American Community Survey reveals a positive relationship between wages and being covered by employer-provided health insurance. As we show below, there is also a positive cross-sectional correlation in our data on Illinois teachers between the salaries paid to teachers who have identical levels of education and teaching experience and health insurance premiums. This suggests it is likely to be very difficult for

${ }^{5}$ Baicker and Chandra's estimate of the wage offset is based on the interaction term between health insurance coverage, as reported by the CPS respondent, and the predicted premium from the first stage IV regression. They cannot estimate a similar model for employee premium copayments because premium copayment data are not collected in the CPS survey.

${ }^{6}$ See Smith and Ehrenberg (1983) for an early discussion of the econometric and data problems in estimating the wage-fringe benefit relationship in the context of wages and pensions. 
researchers to be confident they are comparing the wages and premiums for workers that face an identical budget constraint, that defined by their marginal revenue product.

The lack of data on the employee's premium copayment, $c_{i t}$, may also explain why past empirical research has often failed to negative relationship between wages and insurance. The Kaiser Family Foundation surveys show that from 1999 to 2011 the mean nominal premium for family coverage among private sector employers increased from $\$ 5791$ to $\$ 15,073$ and the mean premium copay has remained virtually unchanged at 27 percent of the mean premium, suggesting that premium copayments have been an important mechanism for shifting some of the premium cost increases to workers through lower take-home pay. ${ }^{7}$ Our Illinois teacher data show the teachers' premium copayment on a family policy has remained relatively unchanged from 1990-91 to 2007-2008 at 34 percent of the total premium. ${ }^{8}$ Examining solely the relationship between salaries and health insurance costs, without incorporating premium copayments, will miss a major mechanism through which take-home pay adjusts to higher premium costs.

The prediction of a dollar-for-dollar trade-off (ignoring the role of taxes) between take-home pay and the cost of health insurance is based on a particular set of assumptions. In the GoldsteinPauly model, employers provide health insurance and employees are willing to pay for these benefits in the form of lower wages because the cost of health insurance is less than, or equal to, the value employees place on the protection the plan provides from unanticipated health shocks to a worker or her dependents. However, health insurance premium differences across firms at a point in time, or within firms over time, will reflect many factors, such as increased health costs due to technological advancements, the size and health status of the employee pool, and the characteristics of the health plan (i.e. deductibles, etc.). Some of these factors, such as the degree of cost sharing, may be easily apparent to employees; others may not. Importantly, not all of the factors affecting premiums may be valued by employees at their cost to the employer.

${ }^{7}$ See Kaiser (2011).

$8 \mathrm{~A}$ regression of the teacher premium copayment as a fraction of the total cost of a family policy on a linear time trend shows a very small increase over time of 0.0015 points per year. This estimate is statistically different from zero $(\mathrm{p}$-value $=.045)$. 
Following Summers (1989), the take-home wage and employment adjustments to premium increases depend on how the premium increases compare to the change in the value employees place on the policy. For example, a decrease in a health insurance plan's annual deductible will reduce enrollee's out-of-pocket costs and therefore increase the valuation employees place on the plan. Thus, we would expect to find that an increase in premiums that derive from a reduction in the deductible to be offset by a reduction in take-home salary. Indeed, Royalty (2008) finds that workers are willing to give up more than a dollar in wages to get an additional dollar's worth of observable plan generosity (such as a lower deductible).

The preceding discussion is based on a competitive labor market where wages and benefits are set in the absence of a union. All public primary and secondary school teachers in Illinois are represented by a local union, as we describe below. As previous studies have noted, the bargaining goals of the union will not reflect those of a union member who is on the margin of working for the firm, but will more likely reflect the preferences of the median union member. ${ }^{9}$ In the context of health benefits, the evidence suggests unions will place more value on health benefits compared to the typically younger marginal worker in a non-union firm because the median union member is likely to be an older worker with a greater demand for health care. ${ }^{10}$ Importantly, however, union and district compensation negotiations will set the union's marginal rate of substitution between wages and benefits equal to the districts marginal willingness to trade-off benefits for wages. A unionized setting does not itself imply that the trade-off between wages and insurance vanishes. A strong union will bargain to increase total compensation, but will also be willing to trade-off health insurance for salary.

\section{Estimating the value of health insurance using data on Illinois public school teachers}

We use data from Illinois public school teacher contacts to overcome many of the empirical obstacles detailed above. The Illinois State Board of Education has conducted a survey of school

\footnotetext{
9 See Goldstein and Pauly (1976); Freeman and Medoff (1984); and Farber (1986).

${ }^{10}$ See Freeman and Medoff (1984).
} 
districts since the early 1990s that collects information on salaries paid to teachers at different points of the salary schedule, the cost of an individual and family health insurance policies (if these policies are offered to teachers), and teacher premium copayments for each of these policies. We use data from primary and secondary school districts in the state that participated in the survey from academic years 1991-92 through 2008-09. There are over 800 districts in the state, though the exact number varies from year to year as some districts consolidated and others were created. Virtually all public school teachers are represented by an affiliate of the Illinois Federation of Teachers (IFT) or the Illinois Education Association (IEA). An IEA affiliate represented teachers in 76 percent of the districts and an IFT affiliate represented teachers in 23 percent of districts and the remaining districts had an unaffiliated local union over our study period. Each school district negotiates a contract (usually a multi-year agreement) with their local union under state legislation that gives teachers the right to strike after proper notification is given to the district of their intent to strike.

In virtually all primary and secondary school districts in Illinois, a teacher's nine-month salary is exactly determined by where their education level and years of teaching experience place them on a two-dimensional salary grid. The salary survey data includes information for seven points on this grid: the minimum salary for a teacher with a BA, the maximum salary for a teacher with a $\mathrm{BA}$, the MA minimum, the MA maximum, a teacher who has an MA and 10 years of experience, the minimum salary for a teacher who has an MA and 30-32 credits, and a the maximum salary for a teacher who has an MA plus 30-32 credits-maximum. The "minimum" salary points specify the compensation for a teacher beginning their teaching career and the salary "maximum" describes pay for someone whose experience equals the salary schedule maximum. The number of years of experience required to reach the salary maximum (conditional on education) varies across districts. In some districts the parties have negotiated "longevity pay" which provides an additional yearly salary increment for teachers whose years of service place them at the maximum step (years) on the salary grid for their years of education. This longevity pay increment is smaller than the pay increment provided by advancing a step on the salary grid. For teachers with a BA (MA) degree the average percentage salary increase for a year of service was 2.70 (2.66) percent for years up to the grid maximum and in districts with longevity pay the average yearly increment was $1.68(0.82)$ 
percent for each year of service beyond the maximum years on the salary grid. ${ }^{11}$ We convert all monetary variables, such as salaries and health insurance costs, to July 2009 dollars using the national CPI for all items.

These data have several strengths that allow us to address the difficulties described above. By estimating a model of the salary paid to teachers with a specific level of credentials (i.e. a master's degree and ten years of teaching experience), we implicitly control for these two measures of worker productivity. In a typical survey (such as the Current Population Survey), experience is often measured imprecisely or not at all and years of education fails to capture the specific kind of training that affects pay. The data we use describes the pay for a college graduate certified to teach in Illinois who has a particular configuration of credentials. That is, we estimate the wage trade-off for a particular job, not for a particular person. This distinction is important because it allows us to abstract from unmeasureable differences in tastes and productivity across people. Of course there is substantial variation across districts in the salary schedules and these differences may capture other important differences in teacher quality that are not captured by education and experience. Our models will attempt to address this by using district fixed-effect models. Moreover, since the analysis is based on data from a single occupation, the wage data do not include unmeasured selection effects related to occupational choice that could be correlated with health insurance premiums or salary.

Most importantly, the data give us access to precise information on insurance costs that are not typically available in other nationally-representative data sources. For each district in each year, the survey includes information on the total premiums for health/hospitalization insurance, prescription drug insurance, disability insurance, life insurance, vision insurance, and dental insurance. Districts report the cost for a single individual (i.e. the teacher) and the extra cost to cover a teacher's spouse and/or dependents. If districts offer more than one plan, they are instructed to

11 Typically the number of yearly "steps" on the salary grid was greater for teachers with an MA degree. The average number of years it took a teacher with a BA to reach the salary grid maximum was 15.5 years for districts offering longevity pay to BA certified teachers. In contrast, the average number of years it took MA certified teachers to reach the maximum step was 19 years in districts offering longevity pay to teachers with an MA.. 
report the cost of the most expensive plan. Unfortunately, the data does not include information about the number of plans offered. We do not know any details about the plan itself, such as what services are covered, cost sharing, etc. We also do not know the insurance take-up rate. Districts report the fraction of the cost of each type of insurance that is paid by the district; we refer to the balance paid by the teacher as the teacher premium copayment. Finally, we analyze the combination of health/hospitalization coverage and prescription drug coverage together. Many districts report a single cost for both of these forms of coverage and so it is not possible to analyze them separately. We do not study the other forms of insurance.

We also only include districts that reported that they offer insurance in all periods in which they participated in the survey. In any given year, about 10 to 15 percent of districts that participate in the survey do not report a cost associated with their health insurance policy. This could mean that the district does not offer health insurance at all. However, in most such cases, the particular year with missing data is both preceded by, and followed by, years in which they report that they offer health insurance. This leads us to suspect that the missing data reflect a lack of reporting rather than a lack of health insurance. So we opt to focus on a sample of districts that report offering insurance in each year that they participate in the survey. As a practical matter, our estimates are not sensitive to including these observations in the analysis or to running models where the salaries are regressed on an indicator that the district reported a cost of insurance. ${ }^{12}$

Table 1 and Figure 1 provide descriptive information on salaries at our sample schools. Figure 1 shows inflation-adjusted average salaries for five points in the salary schedule over time. Table 1 shows the mean and standard deviation of salaries in 1991, 2000, and 2008. To be clear, these data do not represent the average salaries over teachers with each particular configuration of credentials; rather, they represent the average salaries over districts with each district receiving equal weight. The table and figure indicate that there was very little real growth in salaries over this 18 -year period. In 1991, the average salary for a teacher with a BA and no teaching experience was $\$ 29,429$

12 Each year, districts report the month and year that their current labor contract expires. In the regressions in Section 4, we estimate models based only on the first year of each contract. As such, we drop observations that do not have a valid year of expiration of the contract. 
(in 2009 dollars); in 2008 the starting salary was $\$ 30,906$. This change corresponds to an annual growth rate of 0.3 percent per year. The average maximum salary that a teacher with a BA could earn was $\$ 43,702$ in 1991 , or 48.5 percent more than the starting salary for a teacher with a BA. The average starting salary for a teacher with an MA in 1991 was $\$ 32,453$, or 10.3 percent higher than the salary for a similarly new teacher who only has a BA.

Figure 2 shows the unweighted average premium for individual health insurance and prescription drug coverage and the average additional premium to cover family members between 1991 and 2008 (these premiums are expressed in 2009 dollars). The averages for 1991, 2000, and 2008 are also reported in Table 1. Individual premiums rose by 89 percent from $\$ 2,969$ in 1991 to $\$ 5,622$ in 2008 , or 3.8 percent per year. Family premiums rose at a 4.6 percent annual rate, from $\$ 5,101$ to $\$ 10,972$.

Insurance premiums for teachers in Illinois were slightly more expensive, but grew at a slightly slower rate, than the national average. The Kaiser/HRET survey began in 1999 and collects information on the characteristics of employer-provided health insurance plans in the private sector and state and local governments (Kaiser 2011). The average premium for individual insurance in 2000 was $\$ 3,090$, about 20 percent less than the average cost of individual insurance for Illinois teachers that year. The premium in 2008 was $\$ 4,708$, about 16 percent less than cost in Illinois. The average annual growth rate of individual insurance premiums in the Kaiser data between 2000 and 2008 was 5.4 percent per year.

Districts increasingly relied on premium copayments to cover a portion of individual and family health insurance costs. Figure 3 shows the fraction of districts that had any premium copayment and Figures 4a shows the unconditional average copayment for individual insurance and the copayment conditional on having a positive copayment. Table 1 shows the unconditional average copayment as a fraction of the average premium in 1991, 2000, and 2008. 39.5 percent of districts had a copayment for individual insurance in 1991 and the average copayment among districts that had one was $\$ 672$, or 23.6 percent of the average premium in these districts. The unconditional average copayment (including zeros for districts without any copayment) was \$266, which represents 9.3 percent of the average premium that year. By 200857.6 percent of districts had a copayment for individual insurance and the average copayment among those that had one was $\$ 1042$, or 18.9 percent of the average premium in these districts. The unconditional average 
copayment was $\$ 601$, or 10.9 percent of the average premium that year. So more districts adopted copayments for individual insurance over time, but the fraction of premiums covered by teacher copayments increased by only 1.6 percentage points. Another way to view the role of premium copayments is to note that the real average premium rose by $\$ 2653$ between 1991 and 2008; $\$ 335$ dollars of this, or 12.6 percent, was paid by teachers directly through increased premium copayments. Districts real expenditures on individual health insurance increased by an average of $\$ 2318$ per teacher.

Premium copayments are more important for family insurance. Figure 4b shows the unconditional average copayment for family insurance and the copayment conditional on having a positive copayment. 81.7 percent of districts had a copayment for individual insurance in 1991 and the average copayment among districts that had one was $\$ 3371$, or 68.6 percent of the average premium in these districts. The unconditional average copayment (including zeros for districts without any copayment) was $\$ 2758$, which represents 60.9 percent of the average premium that year. By 200890.7 percent of districts had a copayment for individual insurance and the average copayment among those that had one was $\$ 6429$, or 60.8 percent of the average premium in these districts. The unconditional average copayment was $\$ 5834$, or 59.8 percent of the average premium that year. As with individual insurance, school districts adopted copayments for family insurance over time and, indeed, by 2008 nine out of 10 districts had a copayment. The fraction of premiums covered by teacher copayments remained essentially the same over time. Between 1991 and 2008 real average premiums for family insurance rose by $\$ 5419$; $\$ 3076$ dollars of this, or 56.8 percent, was paid by teachers directly through increased premium copayments. Districts real expenditures on family health insurance increased by $\$ 2343$ per enrolled family, on average, which is almost exactly the increase that districts paid for individual insurance during this period.

Figure 5 shows the cross-sectional relationship in 2008 between premiums for individual health insurance and the salary for a teacher with a master's degree and 10 years of teaching experience. The slope of a bivariate regression line through the data is 0.58 with a standard error of 0.27 , which indicates that a $\$ 100$ increase in premiums is associated with $\$ 58$ higher salary. We interpret this positive cross-sectional relationship as a reflection of other, potentially unobservable factors that lead some districts to offer both high wages and more expensive health insurance. For 
example, districts in richer neighborhoods are likely to offer relatively higher compensation to attract and retain high-quality teachers.

The advantage of panel data is that we can correlate changes in the cost of insurance in a particular district over time with changes in the premium copayments and salaries in the district and purge any time-invariant district characteristics. Figure 6 shows the relationship between changes in the real cost of individual health insurance between 1999-2001 and 2006-2008, on the one hand, and the change in the real salary paid to a teacher with an MA and ten years of teaching experience. ${ }^{13}$ The scatter plot reveals that there is quite a bit of variation in the real change in health insurance costs during this period, with many experiencing little or no growth and others experiencing upwards of a $\$ 5000$ increase in insurance costs. The slope of the bivariate regression line is 0.03 with a standard error of 0.10 . That is, changes in health insurance costs are virtually uncorrelated with changes in salary; a $\$ 100$ increase in premiums is associated with a $\$ 3$ increase in wages, though the estimate is not statistically different from zero. Importantly, virtually all of the positive correlation in the cross-section disappears once we look at within-district changes. That pattern remains once we move to the regression framework in Section 4.

Finally, Figure 7 is a scatter plot of changes in the real cost of individual health insurance between 1999-2001 and 2006-2008, on the one hand, and changes in the premium copayment for this insurance. The slope of the bivariate regression line is 0.21 with a standard error of 0.02 , indicating that a $\$ 100$ increase in premiums is associated with a $\$ 21$ increase in teachers’ premium copayment.

\section{Regression estimates of the relationship between premiums, salary, and copayments.}

This section presents regression estimates of the relationship between health insurance premiums, salaries, and premium copayments. The basic wage regression is

$$
w_{i t}=\alpha+\beta h_{i t}+\gamma X_{i t}+\lambda_{t}+v_{i}+e_{i t}
$$

where $w_{i t}$ is a point on the salary schedule (such as the starting salary for teacher with a BA) of district $i$ in year $t . h_{i t}$ is the total annual health insurance premium for either the teacher or for

\footnotetext{
${ }^{13}$ Averaging over three years reduces the attenuating effect of measurement error.
} 
family members. $X_{i t}$ represents time-varying covariates and includes the log of average daily attendance in the district, the log of real assessed value of local property per student in the district, and the log of real federal and state aid to the district per student. The non-compensation data are collected separately by the Illinois State Board of Education. Our preferred specification includes both district $\left(v_{i}\right)$ and year fixed effects $\left(\lambda_{t}\right)$. To highlight that the cross-sectional correlation between salaries and health insurance is quite different from the correlation within districts over time, we also present models that omit the district fixed effects. ${ }^{14}$ Finally, $e_{i t}$ represents the unobservable error term. We also present similar models of the copayment, $c_{i t}$, for individual or family insurance as a function of health insurance premiums.

As we noted above, we estimate these models only using observations associated with the first year of each district contract. Most contracts last between one and three years. If wages are fixed (or change in a pre-determined manner) during the course of a contract, while the cost of health insurance is adjusted annually, then including observations from each year in the regression will tend to underestimate the responsiveness of wages to health insurance costs. Including these observations would also heighten biases associated with misspecification of any lag structure between changes in health insurance and changes in wages. As a practical matter, our estimates are virtually unchanged if we include all years of each contract.

Our preferred regression estimates include district and year fixed effects. This means that identifying variation in health insurance premiums comes from differential changes in premiums within districts over time. As shown in Figures 6 and 7, premiums rose (or fell) more in some districts than in others. This variation in premiums could come from a number of sources: districts could alter the details of their insurance plans by, for example, changing their physician network, the degree of cost sharing, switching between and HMO and a PPO. Within-district changes in premiums could also result from different health experiences of teachers and their families, as premiums rise disproportionately more in districts that experience more adverse health events.

The near steady increase in real premium costs (See Figure 2) over the 18 year study period suggests that the premium increases in our data are being driven by the continual increase in the cost

${ }^{14}$ We cluster the standard errors at the school district level in models that do not contain district fixed effects. 
of medical care and the major factor thought to explain the persistently high level of growth in medical spending in the U.S. over the last fifty years is technological innovations in medical care (Chernew \& Newhouse 2011). In our study the premium variation used to identify the impact of health insurance premiums on salaries and teacher copays could come from the uneven impact of new technologies on the local cost of health care if there is variation across health markets in the adoption rates of new medical technologies. Evidence suggesting this may be important come from numerous studies (e.g. Phelps 2000; Skinner 2011) that show the adoption rates of new medical technology vary across markets for reasons not easily explained by prices, income or characteristics of the patient population, even when the technology is low cost and clearly clinically effective. ${ }^{15}$ Differences in adoption rates of new technology across markets for a single technology will generate different changes in health insurance premium costs across employers. More importantly, the continual development of new medical technologies, their uncertain impact on health care expenditures and differences in adoption rates across health care markets, suggest health insurance premiums over time and across employers are subject to random shocks that reflect the stream of past innovations and heterogeneity in adoption rates across both technologies and health care markets.

Though we do not have data on the diffusion and development of new technologies in Illinois that might directly explain this premium variation, we can provide indirect evidence that shows this premium variation is correlated with the identity of the hospital markets where each school district is located. To show this, first note that the variation in premium costs used to identify the impact of premiums on salaries and teacher copays in models with school district and year fixed effects is the variation in premiums defined by the complete set of school district and year interactions. We constructed this residual variation in premiums by regressing health insurance premiums for individual coverage on the three variables included in the salary and copay regressions

${ }^{15}$ For example, in 1985 the medical evidence clearly showed that taking beta blockers after an individual has had a heart attack is both very cost effective and it substantially improves health outcomes. However, by 2000-2001 state level data show that only $2 / 3$ of the patients that should take beta blockers were taking beta blockers in the median state (Skinner and Staiger 2007). 
(district size, district wealth and federal and state aid) plus school district and year fixed effects. The Center for Medicare and Medicaid Services (CMS) has identified the different geographic markets served by acute care hospitals in the U.S. The identity of the hospital market serving each school district was determined by matching each school district to one of the 19 different hospital referral regions in Illinois using zipcode information. The health premium residuals were then regressed on a set of year, hospital referral region, and year by hospital referral region indicator variables. Without the interaction terms the main effects of year and hospital market were each jointly different from zero with p-values less than .0001 and an $\mathrm{R}^{2}$ of .096. The $\mathrm{R}^{2}$ increased to .146 when the year by hospital referral region indicators were added to the model. ${ }^{16}$ These estimates indicate that a significant amount of the variation in premiums used to identify the impact of premiums on salaries and copays is related to the markets served by the different hospitals in the state. This market-level premium variation could be caused by differences in technological diffusion, but could also reflect differences across markets in physician practice styles, the wages of medical service providers, among other things.

Table 2 presents results of OLS regressions of the annual premium for individual health insurance on the minimum and maximum salaries for teachers with a B.A. (in Panels A and B) and an M.A. (in Panels C and D). ${ }^{17}$ Results in the first model in Panel A, which does not include district fixed effects, indicates that a dollar increase in the premium for individual health insurance is associated with a 0.19 dollar increase in the salary for a teacher who has a B.A. degree but no teaching experience. The second model includes district fixed effects and indicates that withindistrict changes in the cost of health insurance are virtually uncorrelated with salaries. The point estimate indicates that a dollar increase in the premium is associated with a 0.007 dollar decrease in the starting salary for a teacher with a B.A. The standard error on this estimate is 0.03 , which effectively rules out any economically meaningful wage offset.

16 The regression results for the family premium are very similar to the individual premium results.

${ }_{17}$ Results are virtually identical to those reported when salaries are measured for a teacher with an MA and 10 years of experience or for a teacher at the top of the salary schedule receiving longevity pay. 
The remaining panels of Table 2 confirm that within-district changes in health insurance premiums are uncorrelated with changes in teachers' salaries. The point estimates indicate that a dollar increase in the real premium for individual health insurance is associated with a 0.03 dollar increase in the maximum salary paid to a teacher with a BA degree, though this estimate is not different from zero. The point estimates for models of the minimum and maximum salary paid to a teacher with an MA indicate that these fall by 0.018 and 0.073 dollars for a dollar increase in health costs. Again, these estimates are not statistically different from zero.

Estimates in Table 3 indicate that changes in the premium for family members' insurance are not meaningfully correlated with changes in teachers' salaries. The first estimate in Panel A, which does not include district fixed effects, indicates that a dollar increase in the premium for family insurance is associated with a 5 cent increase in the salary for a teacher who has a B.A. and no teaching experience. The standard error on this estimate is 0.03 (or 3 cents) and so the estimate is not statistically different from zero. Nevertheless, it is interesting to note that, unlike the models of the cost of individual insurance which showed quite strong cross-sectional correlations between health insurance costs and wages, these models show very little cross-sectional correlation. Our preferred estimates are those that include district fixed effects and these too show very small, if any, correlation between changes in the cost of family health insurance and salaries. For example, the second column of Panel A indicates shows that a dollar increase in the cost of a family health insurance plan is associated with 0.02 dollar increase in the salary of teachers who have a B.A. and no teaching experience. The standard error of this estimate is 0.01 , and so the coefficient is statistically different from zero, but is nevertheless close enough to zero to not be meaningfully different. The other panels also show small, positive associations between changes in the cost of family health insurance plans and teachers' salaries. Our interpretation of these positive estimates that they may reflect a small upward bias as districts that offer more expensive family plans also pay higher wages. However, there is no reason to believe that this bias is large enough to mask large wage offsets.

Teachers pay a meaningful portion of their health insurance costs through premium copayments, as documented in Table 4. The left two columns show results from models of the copayment for individual insurance on the premium for individual insurance, without and with district fixed effects. The model that includes fixed effects, column 2, indicates that a dollar increase 
in the premium for individual health insurance is associated with a 0.17 dollar increase in teachers' premium copayment. The standard error on this estimate is 0.01 . The model without district fixed effects produces a coefficient of 0.16 . The third and fourth columns present estimates of the effect of premiums for family health insurance on the copayment for family insurance. The fourth column, which shows results from a model that includes district fixed effects, indicates that a dollar increase in the premium for family health insurance is associated with a 0.46 dollar increase in the premium copayment. The standard error on this estimate is 0.01 . The model that does not include a district fixed effect produces a coefficient of 0.40 .

The last two columns of Table 4 present models where the dependent variable is the sum of the copayments for individual and family coverage (recall that, in this survey, "family coverage" refers to the additional costs to cover a teacher's spouse and/or dependents). The penultimate column includes the premiums for individual and family coverage separately in the regression and the results are largely the same as those in columns 2 and 4 . The final column models the combined copayment as a function of the combined premium and the results indicate that a dollar increase in the combined premium is associated with a 0.41 dollar increase in the copayment. This indicates most of the variation in the combined premium and copayments stems from variation in the family premium and copayment.

The conclusion from Tables 2 and 3 is that changes over time within a district in the cost of individual and family health insurance plans are largely uncorrelated with changes in teachers' salaries. However, Table 4 shows that teachers pay about 17 percent of the cost of individual insurance and about 46 percent of the cost of family members' insurance through premium copayments. These conclusions are robust to a host of alternative specifications. ${ }^{18}$ The lack of

${ }^{18}$ The Teacher Service Records that we discuss in Section 5 also contain information on the salaries of the school district superintendent, elementary school principals, junior high school principals, and high school principals and we ran models of their salaries as a function of teachers' health insurance premiums. Interestingly, here we did find evidence of a negative association between insurance and wages. For example, pooling all of these administrators together, we find that a dollar increase in teachers' individual health insurance is associated with a 0.345 dollar decline in salary (with a standard error of 0.178 ). The administrators are not part of the teachers' labor union and we suspect that this may help explain why there is 
correlation between wage and premium changes is not driven by wages being fixed within a multiyear contract because our estimates are based on changes from one contract to the next. Figure 6 showed a similar lack of correlation between changes in wages and premiums between 1999 and 2008, which gives us further confidence that our results aren't driven by shorter-term wage stickiness or the presence of measurement error in the premium data.

\section{The impact of the teacher experience distribution on wage and premium copayment offsets}

As noted earlier, several studies have found the wage offset from health insurance benefits are larger for some demographic groups that have higher than average expected health care expenditures. These findings could reflect sorting across employers where groups with higher health care needs work for employers with more generous health insurance and are willing to accept lower cash compensation because of the higher value they place on the better coverage relative to other groups. These effects could also reflect within-firm wage differentials between workers based on their expected utilization of health care services. Our data are uniquely suited for estimating how both salary and premium copayments adjust within districts over time because we have information on the distribution of teachers' experience within each school district for the final seven years of our study period. We use individual teacher-level data from the Illinois Board of Education's Teacher Service Records (TSR). These are administrative data reported by districts to the state Board of Education and contain one record per teacher, administrator, and staff member in the school. The data contain information on the highest degree held; years of experience in the district, state, and out of state; and the individual's job, among other things. This data is available beginning in 2002 .

To assess the differential impact of premiums on districts that employ teachers with highertenured teachers, we first compute the $20^{\text {th }}$ through $80^{\text {th }}$ percentile of the distribution of tenure within each district in each year. We then augment Equation 2 with the seven values for these deciles of the experience distribution and the seven decile values interacted with a health insurance

a wage offset for them. Alternatively, it could be that administrators do not pay premium copayments. In any case, we do not have the data to further address these findings. 
premium measure. We estimated models of both wages and copayments, but only models of the copayments showed statistically significant effects and so we focus on those. Panel A of Appendix Table 1 shows results from two models: the dependent variable in the first column is the copayment for family insurance and the premium measure is the premium for family insurance. The dependent variable in the second column is the sum of the copayments individual and family insurance and the premium measure is sum of premiums for individual and family insurance. The remaining rows show the coefficients on the main effects of the $20^{\text {th }}$ through $80^{\text {th }}$ percentiles of each districts tenure distribution and the interactions between these and the premium measure. In both models, the main effects and interaction effects are jointly statistically different from zero. ${ }^{19}$

Table 5 translates the estimates in Appendix Table 1 by reporting $\partial$ (Family Copay)/ $\partial$ (Family Premium) evaluated at hypothetical teacher tenure distributions that correspond to a "less experienced", “ average experienced”, and "highly experienced” teacher workforce. These distributions of teacher experience are presented in Panel B of Appendix Table 1 and correspond to the $25^{\text {th }}, 50^{\text {th }}$, and $75^{\text {th }}$ percentiles of each point in the tenure distribution across districts. For example, the top row of Panel B indicates that the $25^{\text {th }}, 50^{\text {th }}$ and $75^{\text {th }}$ percentiles of the $20^{\text {th }}$ percentile of the within-firm distribution were equal to 3, 4 and 6 years. The first column indicates that our hypothetical district with a "less experienced" workforce had a median value of teacher tenure of nine years. The "average experienced" district had a median value of 11 year and the "highly experienced" district had a median tenure of 14 years.

The first row of Table 5 shows $\partial$ (Family Copay) $/ \partial$ (Family Premium) is equal to $\$ 0.41$ in the "less experienced" workforce, $\$ 0.46$ for the average workforce and $\$ 0.56$ for the "highly experienced" workforce. That is, districts with longer-tenured teachers tend to have larger premium copayments. The larger gap between the average and more experienced workforce compared to the

${ }^{19}$ We also estimated simpler models with interactions between the premium and just the district's mean or median level of teaching experience. These interaction terms were statistically significant in all of the teacher copay models and the magnitudes of the estimated effects were larger for the model with mean tenure, but both estimates of the offset effects were smaller than the estimates using the seven points of the tenure distribution. This indicates the copay offset effect depends on the overall shape of the experience distribution. 
gap between the less experienced and average workforce is because the difference in years of experience for most of the seven decile values is greater between the $75^{\text {th }}$ and $50^{\text {th }}$ percentiles than between the $25^{\text {th }}$ and $50^{\text {th }}$ percentile. The last column of numbers shows the estimated effect of aging any of the distributions by one year. A rightward shift of the experience distribution by one year increases the copay by three cents for every dollar increase in the family premium.

The second row of Table 5 show estimates of $\partial$ (Individual + Family Copay) / $\partial$ (Individual+Family Premium); the change in the total copay for teacher and family coverage with respect to a change in the total cost of covering both the teacher and his/her dependents.

Compared to the first row, which shows the marginal change in the copay relative to a change in the marginal cost of family coverage, these copayment offsets are about six percentage points smaller for each of the three tenure distributions. Finally, the estimated effect of a one year shift in the tenure distribution is only slightly larger (\$0.031 versus $\$ 0.033$ ). This suggests that virtually all of the effect of the teacher experience distribution on the total copay for self and dependent coverage is due to the impact of experience on the marginal change in the family copay response to a marginal change in the cost of the family coverage premium. ${ }^{21}$

These results are consistent with the results reported in Tables 2-4; all the adjustment in cash compensation to changes in health insurance premium costs come through changes in teacher premium copayments rather than adjustments to salary. The estimates indicate that the teachers in districts with a more experienced and older workforce place a greater value on the health benefits associated with higher family premiums relative to a district with a less experienced and younger workforce.

\section{Understanding how health insurance costs influence school districts}

Teachers' premium copayments account for about 17 percent of the cost of individual insurance and about 46 percent of the cost of family insurance. The tax exclusion can account for

${ }^{21}$ We formally confirmed this conclusion by including the tenure interaction terms in the Individual copay $=$ $\mathrm{f}$ (individual premium) model. The experience and experience by individual premium terms were jointly insignificant in this model. 
perhaps 15 to 25 percent of the cost, depending on the average marginal tax rate of teachers in the district. This implies that a large share of the incidence of health insurance costs falls on the district. This section explores alternative hypotheses that could explain how schools respond to increased health insurance costs.

When faced with higher compensation costs, do districts simply move up their labor demand schedule and hire fewer teachers? Estimates presented in Table 6 indicate that the answer is no. This table reports results of regressions of the log of the number of teachers in a district on the log of various compensation measures. These models all include district fixed effects and the log of average daily attendance in the district, the log of real assessed value of local property per student in the district, and the log of real federal and state aid to the district per student. These are essentially regressions of quantities on prices and are therefore potentially subject to the standard concerns about simultaneity. However, because we are dealing with union negotiated contracts where teachers have negotiated a wage premium above market wages, if school boards are free to set employment levels, these estimates reflect movement along the labor demand curve. ${ }^{22}$ The model in column 1 separately includes the $\log$ of the salary for a teacher with an M.A. and 10 years of teaching experience, the log of the premium for individual health insurance, and the log of teachers' premium copayment. None of the compensation variables is statistically associated with the log of the total number of teachers in the district. Columns 2 and 3 present results from alternative specifications. Column 2 includes the $\log$ of salary and the $\log$ of the difference between the health insurance premium and the teacher's copayment. Column 3 simply includes the log of the salary plus the individual health insurance premium less the teacher's copayment. Neither of these specifications

22 This ignores two potentially confounding factors. First, employment will not fall on the district's labor demand curve if the parties bargain for the more efficient contract that sets both salaries and employment levels rather than just compensation levels (Brown and Ashenfelter 1986, MaCurdy and Pencavel 1986) For a discussion of this literature see Pencavel (1991) and Booth (1995). Second, many of the school districts in the state are in lightly populated rural areas where districts may have some monopsony power. We leave these issues for later research and view our estimates as suggestive of a relationship between compensation costs and employment levels. 
reveal any statistically significant correlation between the number of teachers and measures of compensation.

The remaining columns of Table 6 report the relationship between compensation measures and the number of pre-kindergarten, kindergarten, elementary school, and secondary school teachers, and teachers in ungraded classrooms (such as music teachers). While some of these models do show a statistically significant relationship between the district's health insurance cost and the number of teachers, the effect sizes are uniformly small and of inconsistent signs: In two models the premium is negatively associated with the number of teachers; in one model the premium is positively associated with the number of teachers; and in two models the coefficient on the premium is not statistically different from zero. We have also run models of the log of the number of nonteacher employees, such as guidance counselors, administrators, and staff, on the teachers' compensation measures and similarly found no evidence of a relationship. We conclude that increased health insurance costs do not seem to lead to reductions in the number of school employees.

Next we assess whether districts respond to rising health insurance costs by switching to less-educated or less-experienced teachers to reduce their total compensation costs. For this analysis we use the individual teacher-level data described in Section 5. From these individual records, we calculate the percentiles of the distribution of total teaching experience among teachers in each district and the fraction of teachers in the district who have a master's degree or more education and match these to the district health insurance and compensation records.

Table 7 reports results of regression models of the $10^{\text {th }}, 30^{\text {th }}, 50^{\text {th }}, 70^{\text {th }}$, and $90^{\text {th }}$ percentiles of the distribution of teacher experience on the log of the salary for a teacher with an MA and 10 years of teaching experience, the log of the premium for individual health insurance (less the teacher copayment), district fixed effects, and the three covariates included in previous models. The means of the level (rather than logs) of each dependent variable are included at the bottom of the table. The estimates indicate there is no statistically significant relationship between health insurance costs and the distribution of teacher experience. The final column of Table 7 indicates that rising health insurance costs is positively associated with the fraction of teachers with an MA degree. Even though this estimate is statistically different from zero and the opposite sign from what we expect, the magnitude of the estimate is extremely small: a doubling of real health insurance costs is only 
associated with a 0.7 percentage point increase in the fraction of teaches with an MA, from a base of 42 percent. Taken together with the results in Table 6, it seems clear that rising health insurance costs have no impact districts' demand for labor, both in terms of the number of teachers or their skill level. ${ }^{23}$

\section{Discussion and conclusions}

Health insurance premiums for Illinois public school teachers increased dramatically over the past twenty years, just as they did nationally. Our analysis indicates quite clearly that changes in premiums within a district over time are uncorrelated with changes in salary. Teachers' take-home pay is reduced by approximately 17 percent of the cost of individual health insurance, and 46 percent of the cost to insure family members, through premium copayments. The offset is larger in districts with relatively higher-tenured teachers. Since teacher premium copayments are paid from pre-tax dollars, the impact of teacher premium copays on after-tax teacher take-home pay is substantially less than $\$ .17$ or $\$ .46$ copay for each dollar increase in premium costs.

We offer two potential interpretations of our findings that each have important implications for thinking about health insurance and compensation. First, the lack of a full offset indicates that premium increases were not associated with commensurate increases in teachers' valuation of their health insurance plans. Several previous studies are consistent with this interpretation. Evidence presented by Royalty (2008) indicates that employees highly value observable measures of health

${ }^{23}$ We also used data from the National Center for Education Statistics' School Finance Survey to verify some of our results. This data contains aggregate school budget variables, such as total annual revenue and expenditures, by category, though it does not separate spending on health insurance from spending on other employee benefits. We found that total spending on employee benefits is positively associated with health insurance premiums and with total instructional spending in regression models that also control for the district-level covariates, year effects, and districts effects. Consistent with the regressions reported in the text, we found no association between premiums and spending on salaries for instructional staff. Since we do not know the insurance take-up rate, whether districts offer multiple health insurance policies, or how much they spend on other employee benefits, it is difficult to push these data further. 
plan generosity. The widely cited paper by Gruber (1994) can be interpreted to show employees only accept wage offsets when premiums increase when they value the medical care changes driving the premium increases. Gruber finds a complete wage offset for the cost of maternity care among married women of child-bearing age when states required that insurance policies cover maternity costs. This conclusion was based on a "difference-in-difference-in-difference" estimator comparing the difference in wage changes before and after the state mandates between married women 20-40 years old and men either over 40 or single men 20-40 years old For the female sample there was a significant wage decline after the mandate was passed but for the comparison group of men there was no significant change in mean wages This suggests the control group of men placed no value on the health benefits provided by maternity coverage. However, since married women of childbearing age are not employed in gender segregated establishments, firms employing both men and women faced higher premium costs because of the maternity mandate but only married women 20-40 years old valued these benefits as indicated by their willingness to accept lower wages following the mandate. Our estimates that show more experienced and older teacher workforces are willing to accept higher premium copayments when premiums increase compared to less experienced workforces is consistent with the previous research that shows wage offsets only for demographic groups that value the benefits changes driving the premium cost increases. As noted earlier, because technological innovation is the leading cause of the overall growth in health care costs in the U.S., our estimates suggest the technologies driving the cost increases are more highly valued by older workers but, on average, these benefits are not valued by employees at their cost to the employer.

A second potential explanation for our results is that both employees and employers are concerned about the uncertain changes in future health insurance costs. If changes in the cost of health insurance are driven by technological innovation in the health care sector, then the premium cost increases are unpredictable to teachers and local taxpayers and the parties negotiate over how this risk is shared when they agree to a teacher premium copay because unpredictable changes in health insurance premiums impose a cost on both employers and employees A full wage offset, as predicted by the traditional model of employee benefits, implies that employees bear all of the risk associated with uncertain health insurance costs. Similarly, the degree to which employers' bear the burden will generate unpredictable fluctuations in their labor costs and local school budgets. If local 
taxpayers are more able or willing to take on some this risks, then we would expect to find less than full wage offset. Testing between these two explanations for less than a full wage offset for health insurance premiums will require better data on the characteristics of insurance policies and the factors generating changes in insurance premium costs.

\section{References}

Baicker, Katherine and Amitabh Chandra. 2006. "The Labor Market Effects of Rising Health Insurance Premiums." Journal of Labor Economics 24, pp. 609-634.

Bhattacharya, Jay and M. Kate Bundorf. 2009. "The Incidence of the Healthcare Costs of Obesity." Journal of Health Economics 28 (3): 649-658.

Booth, Alison L. 1995. The Economics of the Trade Union. New York: Cambridge University Press.

Brown, Charles. 1980. "Equalizing Differences in the Labor Market.” The Quarterly Journal of Economics 94 (1): pp. 113-134.

Brown, James N. and Orley Ashenfelter. 1986. "Testing the Efficiency of Employment Contracts." Journal of Political Economy 94 (3, Part 2: Hoover Institution Labor Conference): pp. S40-S87.

Chernew, Michael E. and Joseph P. Newhouse. "Chapter One - Health Care Spending Growth.” In Handbook of Health Economics. Vol. Volume 2, 1-43: Elsevier.

Currie, Janet and Brigitte C. Madrian. "Chapter 50 Health, Health Insurance and the Labor Market." In Handbook of Labor Economics. Vol. Volume 3, Part C, 3309-3416: Elsevier.

Eberts, Randall W. and Joe A. Stone. 1985. "Wages, Fringe Benefits, and Working Conditions: An Analysis of Compensating Differentials," Southern Economic Journal, Volume 52, Number 1 (July), pp. $274-280$.

Farber, Henry S. 1986. "Chapter 18 the Analysis of Union Behavior.” In Handbook of Labor Economics. Vol. Volume 2, 1039-1089: Elsevier. 
Freeman, Richard B. and James L. Medoff. 1984. What do Unions do? Basic Books.

Goldstein, Gerald S. and Mark V. Pauly. 1976. "Group Health Insurance as a Local Public Good." In The Role of Health Insurance in the Health Services Sector, edited by Richard N. Rosett, 73-114: National Bureau of Economic Research, Inc.

Gruber, Jonathan. 1994. "The Incidence of Mandated Maternity Benefits." The American Economic Review 84 (3): pp. 622-641.

Kaiser Family Foundation and Health Research and Educational Trust. 2011. Employer Health Benefits 2011 Annual Survey.

Kolstad, Jonathan T. and Amanda E. Kowalski. 2012. "Mandate-Based Health Reform and the Labor Market: Evidence from the Massachusetts Reform,” NBER Working Paper No. 17933.

Lehrer, Steven F. and Nuno Sousa Pereira. 2007. "Worker Sorting, Compensating Differentials and Health Insurance: Evidence from Displaced Workers." Journal of Health Economics 26 (5): 10341056.

Levy, Helen and Roger Feldman. 2001. "Does the Incidence of Group Health Insurance Fall on Individual Workers?” International Journal of Health Care Finance and Economics 1 (3-4): 227-247.

MaCurdy, Thomas E. and John H. Pencavel. 1986. "Testing between Competing Models of Wage and Employment Determination in Unionized Markets." Journal of Political Economy 94 (3, Part 2: Hoover Institution Labor Conference): pp. S3-S39.

Olson, Craig A. 2002. "Do Workers Accept Lower Wages in Exchange for Health Benefits?” Journal of Labor Economics 20 (S2, Compensation Strategy and Design, Sponsored by WorldatWork): pp. S91-S114.

Pencavel, John H. 1991. Labor Markets Under Trade Unionism : Employment, Wages, and Hour. Cambridge, USA: B. Blackwell. 
Phelps, Charles E. 2000. “Chapter 5 Information Diffusion and Best Practice Adoption.” In Handbook of Health Economics. Vol. Volume 1, Part A, 223-264: Elsevier.

Rosen, Sherwin. 1986. “Chapter 12 the Theory of Equalizing Differences.” In Handbook of Labor Economics. Vol. Volume 1, 641-692: Elsevier.

Royalty, Anne Beeson. 2008. “Estimating Workers' Marginal Valuation of Employer Health Benefits: Would Insured Workers Prefer More Health Insurance or Higher Wages?” Journal of Health Economics, Volume 27, Issue 1 (January), pp. 89-105.

Sheiner, Louise. 1999. Health Care Costs, Wages, and Aging: Board of Governors of the Federal Reserve System.

Simon, Kosali Ilayperuma. 2001. "Displaced Workers and Employer-Provided Health Insurance: Evidence of a Wage/Fringe Benefit Tradeoff?” International Journal of Health Care Finance and Economics 1 (3-4): 249-271.

Skinner, Jonathan and Douglas Staiger. 2007. "Technology Adoption from Hybrid Corn to BetaBlockers in Brendt \& Hulten (eds) Hard to Measure Goods and Services:Essays in Honor of Zvi Griliches. U of Chicago Press \& NBER.

Skinner, Jonathan. 2011. "Chapter Two - Causes and Consequences of Regional Variations in Health Care." In Handbook of Health Economics. Vol. Volume 2, 45-93: Elsevier.

Smith, Robert S. and Ronald G. Ehrenberg. 1983. "Estimating Wage-Fringe Trade-Offs: Some Data Problems.” In The Measurement of Labor Cost, edited by Jack E. Triplett, 347-370: National Bureau of Economic Research.

Summers, Lawrence H. 1989. "Some Simple Economics of Mandated Benefits." The American Economic Review 79 (2, Papers and Proceedings of the Hundred and First Annual Meeting of the American Economic Association): pp. 177-183. 
Table 1: Descriptive statistics for salaries, insurance premiums, and copayments

\begin{tabular}{|c|c|c|c|}
\hline & 1991 & 2000 & 2008 \\
\hline BA minimum salary & $\begin{array}{l}\$ 29,429 \\
(4,084)\end{array}$ & $\begin{array}{c}\$ 30,794 \\
(4,078)\end{array}$ & $\begin{array}{l}\$ 30,906 \\
(4,289)\end{array}$ \\
\hline BA maximum salary & $\begin{array}{l}43,702 \\
(7,887)\end{array}$ & $\begin{array}{l}45,755 \\
(7,693)\end{array}$ & $\begin{array}{l}45,867 \\
(8,002)\end{array}$ \\
\hline MA minimum salary & $\begin{array}{l}32,453 \\
(4,863)\end{array}$ & $\begin{array}{l}34,119 \\
(4,921)\end{array}$ & $\begin{array}{l}34,226 \\
(5,104)\end{array}$ \\
\hline MA maximum salary & $\begin{array}{c}53,428 \\
(12,240)\end{array}$ & $\begin{array}{c}57,768 \\
(12,377)\end{array}$ & $\begin{array}{l}58,043 \\
(12,352)\end{array}$ \\
\hline MA plus 10 year of experience & $\begin{array}{l}42,530 \\
(8,195)\end{array}$ & $\begin{array}{l}44,326 \\
(8,351)\end{array}$ & $\begin{array}{l}44,023 \\
(8,532)\end{array}$ \\
\hline Premium for individual health insurance & $\begin{array}{l}2,969 \\
(874)\end{array}$ & $\begin{array}{l}3,900 \\
(930)\end{array}$ & $\begin{array}{c}5,622 \\
(1,445)\end{array}$ \\
\hline Premium for family health insurance & $\begin{array}{c}5,101 \\
(2,041)\end{array}$ & $\begin{array}{c}6,602 \\
(2,386)\end{array}$ & $\begin{array}{l}10,972 \\
(4,128)\end{array}$ \\
\hline $\begin{array}{l}\text { Copayment for individual insurance } \\
\text { (as a percentage of the total premium) }\end{array}$ & $\begin{array}{l}9.3 \% \\
(17.7)\end{array}$ & $\begin{array}{l}8.7 \% \\
(15.4)\end{array}$ & $\begin{array}{l}10.9 \% \\
(16.4)\end{array}$ \\
\hline $\begin{array}{l}\text { Copayment for family health insurance } \\
\text { (as a percentage of the total premium) }\end{array}$ & $\begin{array}{c}60.8 \\
(39.1)\end{array}$ & $\begin{array}{c}59.2 \\
(37.6)\end{array}$ & $\begin{array}{c}59.8 \\
(34.7)\end{array}$ \\
\hline Number of disctricts & 597 & 494 & 655 \\
\hline
\end{tabular}

Note: All figures are in 2009 dollars. Copayment is the average fraction of the total premium that is paid by teachers for individual or family insurance, including zeros for teachers that have no copayment. Standard deviations in parentheses. 
Table 2: Regression estimates of the effect of individual health insurance on four points in the salary schedule

\begin{tabular}{|c|c|c|c|c|}
\hline \multirow[b]{2}{*}{ Premium for individual insurance } & \multicolumn{2}{|c|}{ BA minimum } & \multicolumn{2}{|c|}{ BA Maximum } \\
\hline & $\begin{array}{c}0.190^{* *} \\
(0.0809)\end{array}$ & $\begin{array}{c}-0.00701 \\
(0.0296)\end{array}$ & $\begin{array}{c}0.389 * * \\
(0.186)\end{array}$ & $\begin{array}{c}0.0269 \\
(0.0788)\end{array}$ \\
\hline Obervations & 3,604 & 3,604 & 3,604 & 3,604 \\
\hline Districts & 686 & 686 & 686 & 686 \\
\hline District fixed effects? & No & Yes & $\mathrm{No}$ & Yes \\
\hline \multirow[b]{2}{*}{ Premium for individual insurance } & \multicolumn{2}{|c|}{ MA minimum } & \multicolumn{2}{|c|}{ MA Maximum } \\
\hline & $\begin{array}{c}0.260^{* * *} \\
(0.0981)\end{array}$ & $\begin{array}{l}-0.0181 \\
(0.0337)\end{array}$ & $\begin{array}{c}0.616^{* * *} \\
(0.225)\end{array}$ & $\begin{array}{l}-0.0731 \\
(0.0886)\end{array}$ \\
\hline Obervations & 3,604 & 3,604 & 3,604 & 3,604 \\
\hline Districts & 686 & 686 & 686 & 686 \\
\hline District fixed effects? & No & Yes & No & Yes \\
\hline
\end{tabular}

*** $\mathrm{p}<0.01,{ }^{* *} \mathrm{p}<0.05, * \mathrm{p}<0.1$

Note: Sample only includes districts that offered insurance in all contracts. All models contain control variables described in the text. Robust standard errors in parentheses are clustered by school district. 
Table 3: Regression estimates of the effect of family health insurance on four points in the salary schedule

\begin{tabular}{|c|c|c|c|c|}
\hline \multirow[b]{2}{*}{ Premium for family insurance } & \multicolumn{2}{|c|}{ BA minimum } & \multicolumn{2}{|c|}{ BA Maximum } \\
\hline & $\begin{array}{r}0.0456 \\
-0.0326\end{array}$ & $\begin{array}{c}0.0239 * * \\
-0.0114\end{array}$ & $\begin{array}{c}-0.0181 \\
-0.065\end{array}$ & $\begin{array}{c}0.0619 * * \\
-0.031\end{array}$ \\
\hline Obervations & 3,002 & 3,002 & 3,002 & 3,002 \\
\hline Districts & 567 & 567 & 567 & 567 \\
\hline \multirow[t]{2}{*}{ District fixed effects? } & No & Yes & No & Yes \\
\hline & \multicolumn{2}{|c|}{ MA minimum } & \multicolumn{2}{|c|}{ MA Maximum } \\
\hline Premium for family insurance & $\begin{array}{l}0.0782^{*} \\
-0.0435\end{array}$ & $\begin{array}{c}0.0255^{* *} \\
-0.013\end{array}$ & $\begin{array}{l}0.0548 \\
-0.079\end{array}$ & $\begin{array}{c}0.0141 \\
-0.0349\end{array}$ \\
\hline Obervations & 3,002 & 3,002 & 3,002 & 3,002 \\
\hline Districts & 567 & 567 & 567 & 567 \\
\hline District fixed effects? & No & Yes & No & Yes \\
\hline \multicolumn{5}{|c|}{$\begin{array}{l}\text { Note: Sample only includes districts that offered insurance in all contracts. All } \\
\text { models contain control variables described in the text. Robust standard errors in } \\
\text { parentheses are clustered by school district. }\end{array}$} \\
\hline
\end{tabular}


Table 4: Regression estimates of the effect of health insurance premiums on premium copayments

\begin{tabular}{|c|c|c|c|c|c|c|}
\hline \multirow[b]{2}{*}{ Premium for individual insurance } & \multicolumn{2}{|c|}{$\begin{array}{c}\text { Copayment for } \\
\text { individual insurance }\end{array}$} & \multicolumn{2}{|c|}{$\begin{array}{l}\text { Copayment for } \\
\text { family insurance }\end{array}$} & \multicolumn{2}{|c|}{$\begin{array}{l}\text { Combined } \\
\text { copayment }\end{array}$} \\
\hline & $\begin{array}{c}0.157 * * * \\
(0.026)\end{array}$ & $\begin{array}{c}0.170 * * * \\
(0.013)\end{array}$ & & & $\begin{array}{c}0.199 * * * \\
(0.051)\end{array}$ & \\
\hline Premium for family insurance & & & $\begin{array}{c}0.400 * * * \\
(0.031)\end{array}$ & $\begin{array}{c}0.458^{* * *} \\
(0.014)\end{array}$ & $\begin{array}{c}0.463 * * * \\
(0.017)\end{array}$ & \\
\hline Combined premium & & & & & & $\begin{array}{c}0.412^{* * *} \\
(0.013)\end{array}$ \\
\hline Observations & 3,624 & 3,624 & 3,019 & 3,019 & 3,019 & 3,019 \\
\hline Districts & & 686 & & 567 & & 567 \\
\hline District fixed effects? & No & Yes & No & Yes & Yes & Yes \\
\hline
\end{tabular}

*** $\mathrm{p}<0.01,{ }^{* *} \mathrm{p}<0.05, * \mathrm{p}<0.1$

Note: Sample only includes districts that offered individual and/or family insurance in all contracts. All models contain control variables described in the text. In models without fixed effects, robust standard errors in parentheses are clustered by school district. 
Table 5: The Estimated Impact of the Teacher Tenure Distibution on $\partial$ Teacher Copay/ $\partial$ Premium

$\partial$ Teacher Copay/OPremium evaluated at:

\begin{tabular}{|c|c|c|c|c|}
\hline & $\begin{array}{c}\text { Low experience: } \\
\mathrm{f}_{.25}(.2), \mathrm{f}_{.25}(.3), \mathrm{f}_{.25}(.4) \\
\mathrm{f}_{.25}(.5), \mathrm{f}_{.25}(.6) \\
\mathrm{f}_{.25}(.7), \mathrm{f}_{.25}(.8)\end{array}$ & $\begin{array}{l}\text { Average experience: } \\
\mathrm{f}_{.5}(.2), \mathrm{f}_{.5}(.3), \mathrm{f}_{.5}(.4) \\
\mathrm{f}_{.5}(.5), \mathrm{f}_{.5}(.6) \\
\mathrm{f}_{.5}(.7), \mathrm{f}_{.5}(.8) \\
\end{array}$ & $\begin{array}{c}\text { High experience: } \\
\mathrm{f}_{.75}(.2), \mathrm{f}_{.75}(.3), \mathrm{f}_{.75}(.4) \\
\mathrm{f}_{.75}(.5), \mathrm{f}_{.75}(.6) \\
\mathrm{f}_{.75}(.7), \mathrm{f}_{.75}(.8)\end{array}$ & $\begin{array}{c}1 \text { year rightward } \\
\text { shift in the } \\
\text { experience distribution }\end{array}$ \\
\hline 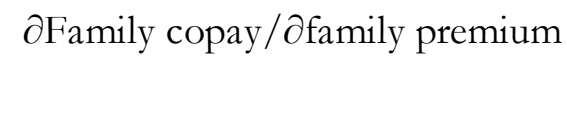 & $\begin{array}{c}0.4072 \\
(0.0374)\end{array}$ & $\begin{array}{c}0.4634 \\
(0.0364)\end{array}$ & $\begin{array}{c}0.5576 \\
(0.0512)\end{array}$ & $\begin{array}{c}0.0314 \\
(0.0126)\end{array}$ \\
\hline $\begin{array}{l}\partial(\text { Individual }+ \text { family copay }) / \\
\partial(\text { Individual }+ \text { family Premium }\end{array}$ & $\begin{array}{c}0.3433 \\
(0.0372)\end{array}$ & $\begin{array}{c}0.3972 \\
(0.0377)\end{array}$ & $\begin{array}{c}0.4973 \\
(0.0536)\end{array}$ & $\begin{array}{c}0.0334 \\
(0.0133)\end{array}$ \\
\hline
\end{tabular}

Note: Standard errors in parentheses. Calculations based on parameter estimates reported in Appendix Table 1. 
Table 6: Regression estimates of the effect of components of compensation on the number of teachers in a district

Log of the number of teachers in each district, by teacher type

Independent variables in logs

Salary for a teacher with an MA \&

10 years of experience

Premium for individual insurance

Teacher's premium copayment for individual insurance

\begin{tabular}{cccccccc}
$\begin{array}{c}\text { Total } \\
\text { teachers }\end{array}$ & $\begin{array}{c}\text { Total } \\
\text { teachers }\end{array}$ & $\begin{array}{c}\text { Total } \\
\text { teachers }\end{array}$ & $\begin{array}{c}\text { Pre- } \\
\text { kindergarten }\end{array}$ & Kindergarten & $\begin{array}{c}\text { Elementary } \\
\text { school }\end{array}$ & $\begin{array}{c}\text { Secondary } \\
\text { school }\end{array}$ & Ungraded \\
\hline 0.0289 & 0.0352 & & 0.253 & $0.248^{*}$ & $0.0929 *$ & -0.0809 & -0.156 \\
$(0.0314)$ & $(0.0314)$ & & $(0.296)$ & $(0.138)$ & $(0.0495)$ & $(0.0792)$ & $(0.112)$
\end{tabular}

$-0.0024$

(0.0057)

0.0029

(0.0029)

Premium less teacher copayment

$\begin{array}{llllll}-0.0009 & -0.0611^{*} & -0.0208 & -0.0063 & 0.0215^{* *} & -0.0361 * * \\ (0.0043) & (0.0323) & (0.0195) & (0.0070) & (0.0104) & (0.0165)\end{array}$

Salary plus premium less copayment

0.0233

(0.0309)

\begin{tabular}{lcccccccc}
\hline Observations & 3,075 & 3,049 & 3,075 & 1,193 & 2,412 & 2,468 & 1,860 & 2,186 \\
Districts & 646 & 645 & 646 & 344 & 548 & 560 & 506 & 555 \\
District fixed effects? & Yes & Yes & Yes & Yes & Yes & Yes & Yes & Yes \\
\hline
\end{tabular}

*** $\mathrm{p}<0.01, * * \mathrm{p}<0.05, * \mathrm{p}<0.1$

Note: Sample only includes districts that offered insurance in all contracts. All models contain control variables described in the text. Robust standard errors in parentheses are clustered by school district. 
Table 7: Regression estimates of the effect of components of compensation on the characteristics of teachers in a district

\begin{tabular}{|c|c|c|c|c|c|c|}
\hline \multirow[b]{2}{*}{ Independent variables in logs } & \multicolumn{5}{|c|}{ Percentiles of the distribution of teacher experience } & \multirow{2}{*}{$\begin{array}{c}\text { Fraction of } \\
\text { teachers with } \\
\text { an MA degree }\end{array}$} \\
\hline & $\begin{array}{l}\text { 10th } \\
\text { percentile }\end{array}$ & $\begin{array}{l}\text { 30th } \\
\text { percentile }\end{array}$ & Median & $\begin{array}{c}\text { 70th } \\
\text { percentile }\end{array}$ & $\begin{array}{l}\text { 90th } \\
\text { percentile }\end{array}$ & \\
\hline $\begin{array}{l}\text { Salary for a teacher with an MA \& } \\
10 \text { years of experience }\end{array}$ & $\begin{array}{l}-0.376 \\
(1.469)\end{array}$ & $\begin{array}{c}0.426 \\
(2.093)\end{array}$ & $\begin{array}{c}-6.015^{* *} \\
(2.767)\end{array}$ & $\begin{array}{l}-7.117 * * \\
(3.052)\end{array}$ & $\begin{array}{l}-4.508 * \\
(2.508)\end{array}$ & $\begin{array}{l}-0.118 \\
(0.082)\end{array}$ \\
\hline Premium less teacher copayment & $\begin{array}{c}0.068 \\
(0.102)\end{array}$ & $\begin{array}{c}0.092 \\
(0.145)\end{array}$ & $\begin{array}{c}0.207 \\
(0.191)\end{array}$ & $\begin{array}{c}0.249 \\
(0.211)\end{array}$ & $\begin{array}{l}-0.047 \\
(0.173)\end{array}$ & $\begin{array}{l}0.010^{*} \\
(0.006)\end{array}$ \\
\hline Mean of dependent variable in levels & 2.665 & 6.820 & 12.063 & 19.271 & 28.831 & 0.418 \\
\hline Observations & 1235 & 1235 & 1235 & 1235 & 1235 & 1235 \\
\hline Districts & 546 & 546 & 546 & 546 & 546 & 546 \\
\hline District fixed effects? & Yes & Yes & Yes & Yes & Yes & Yes \\
\hline
\end{tabular}

*** $\mathrm{p}<0.01$, ** $\mathrm{p}<0.05,{ }^{*} \mathrm{p}<0.1$

Note: Sample only includes districts that offered insurance in all contracts. All models contain control variables described in the text. Robust standard errors in parentheses are clustered by school district. 
Figure 1: Real average salaries by degree and experience, 1991-2008

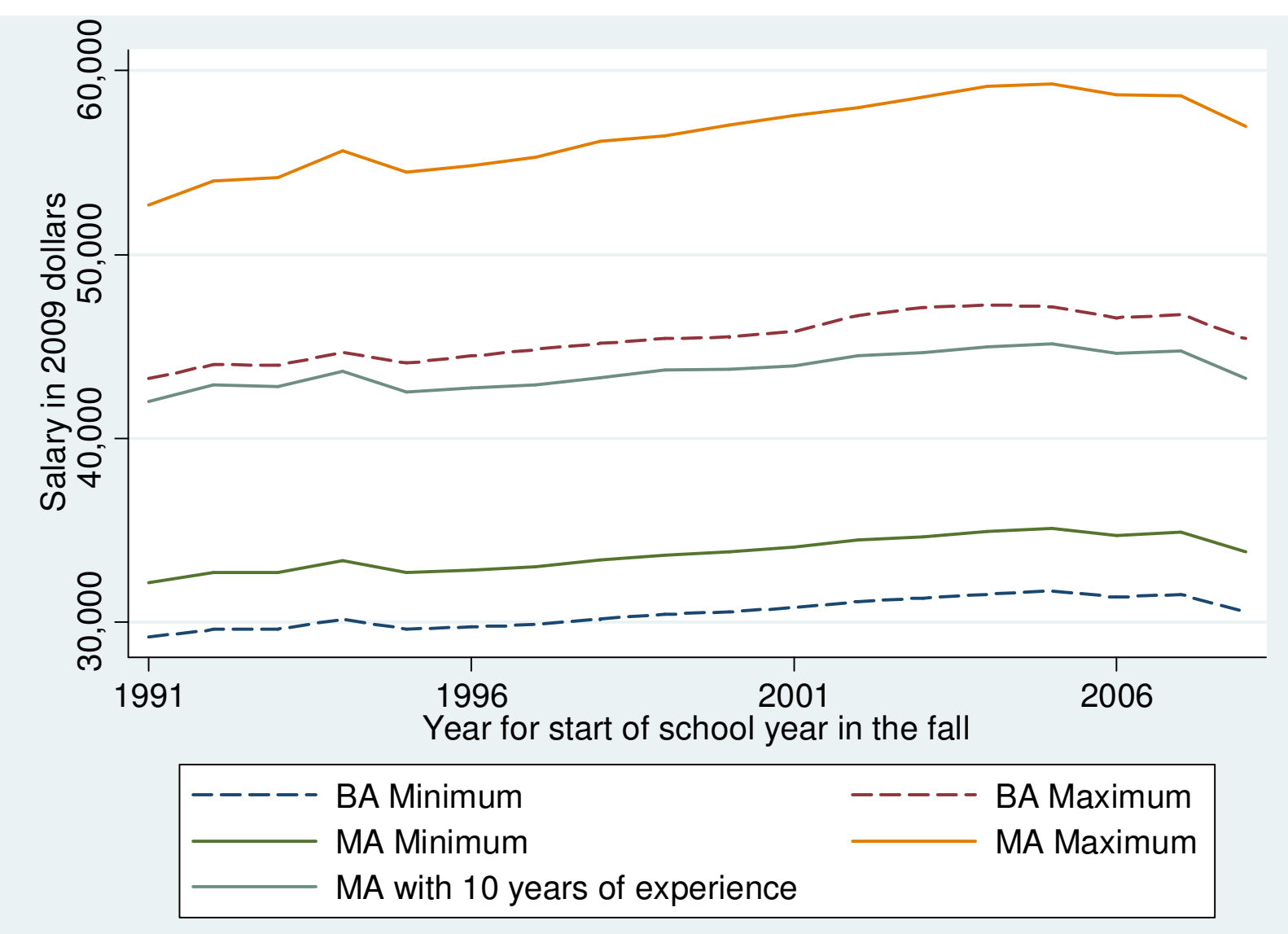


Figure 2: Average health insurance premiums, 1991 to 2008

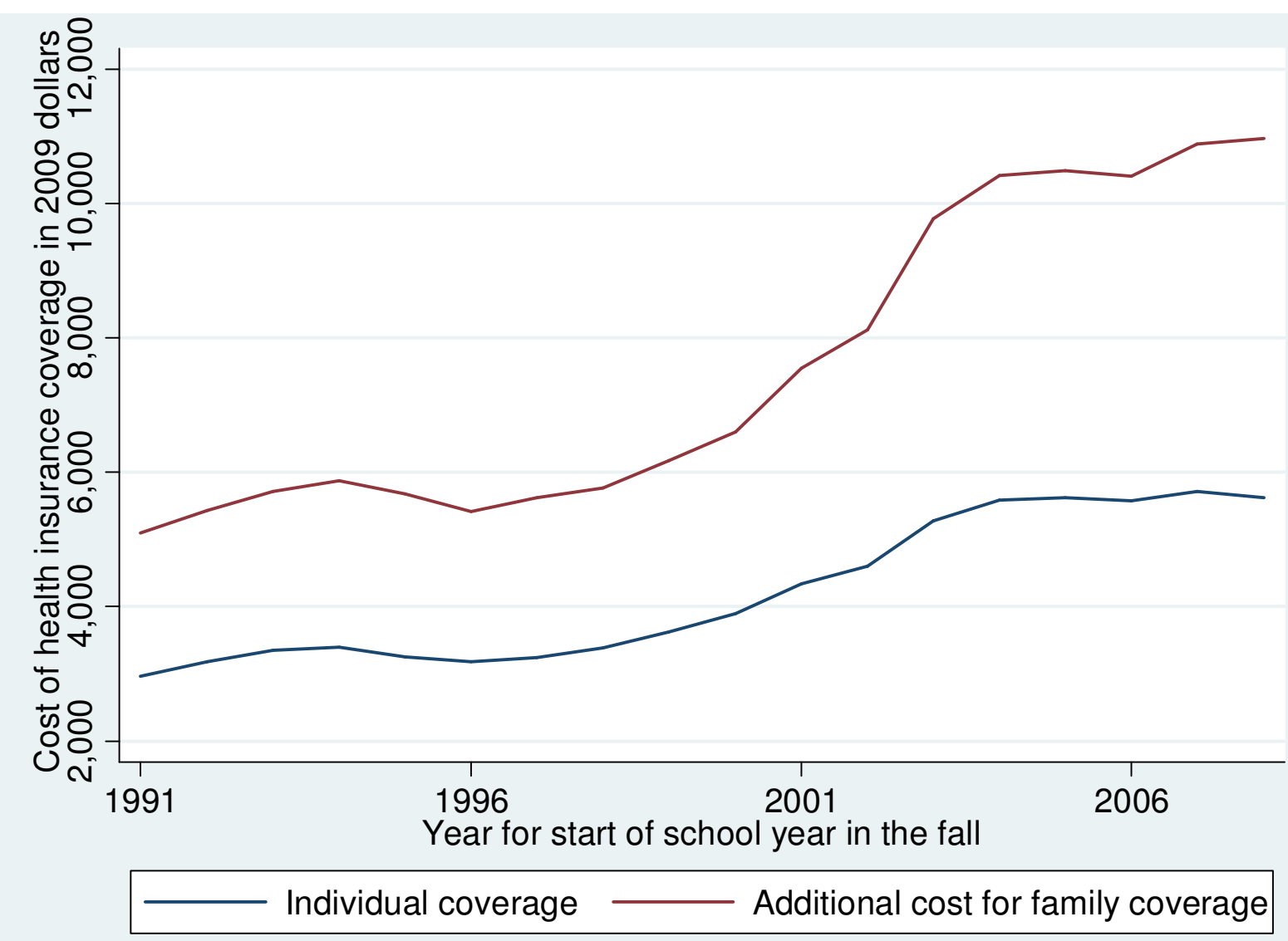

Note: data refer to the cost of health insurance and drug coverage 
Figure 3: Fraction of districts that require an employee premium-copayment for individual or family insurance, $1991-2008$

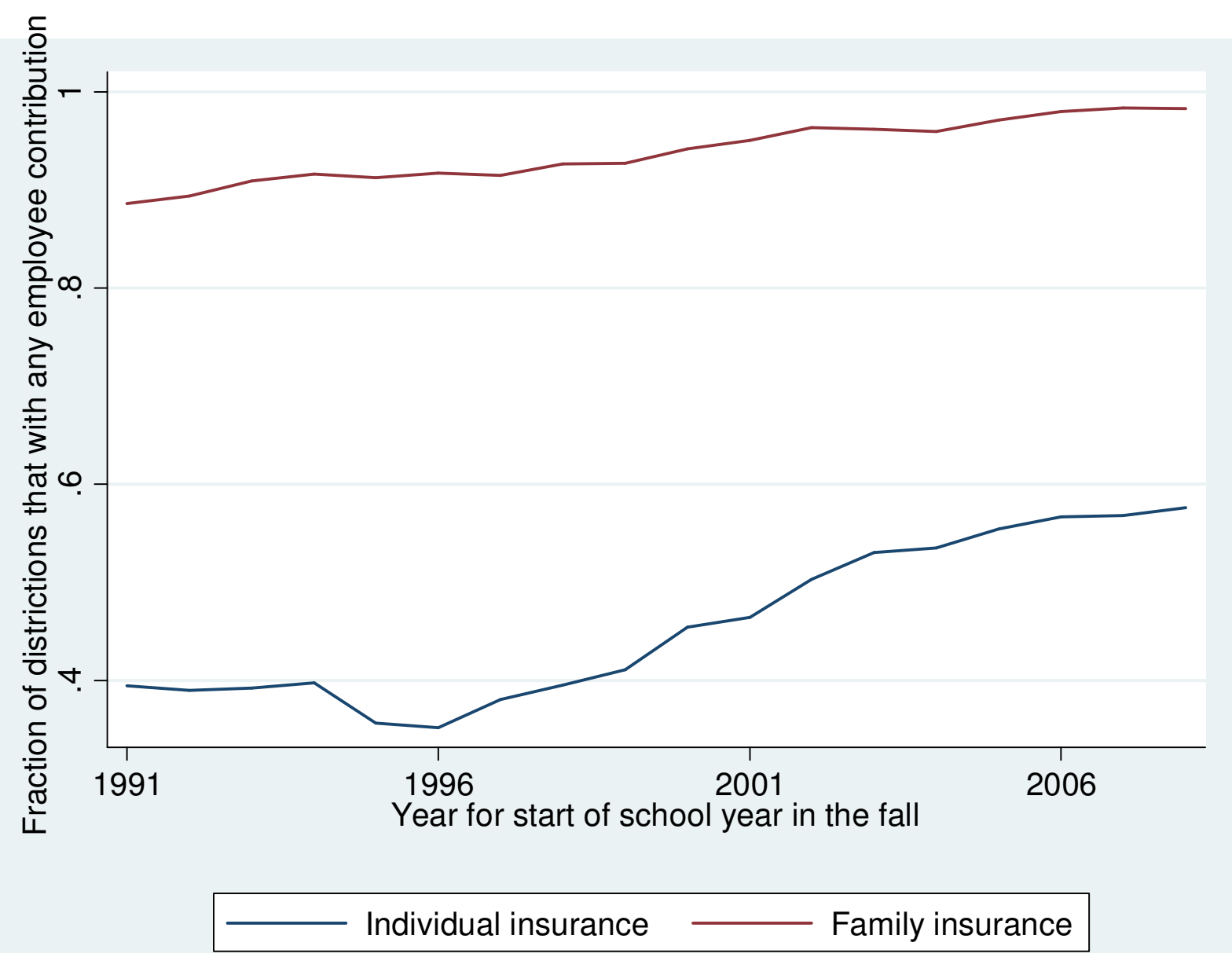


Figure 4a: Copayments for individual insurance as a fraction of total premium, 1991-2008

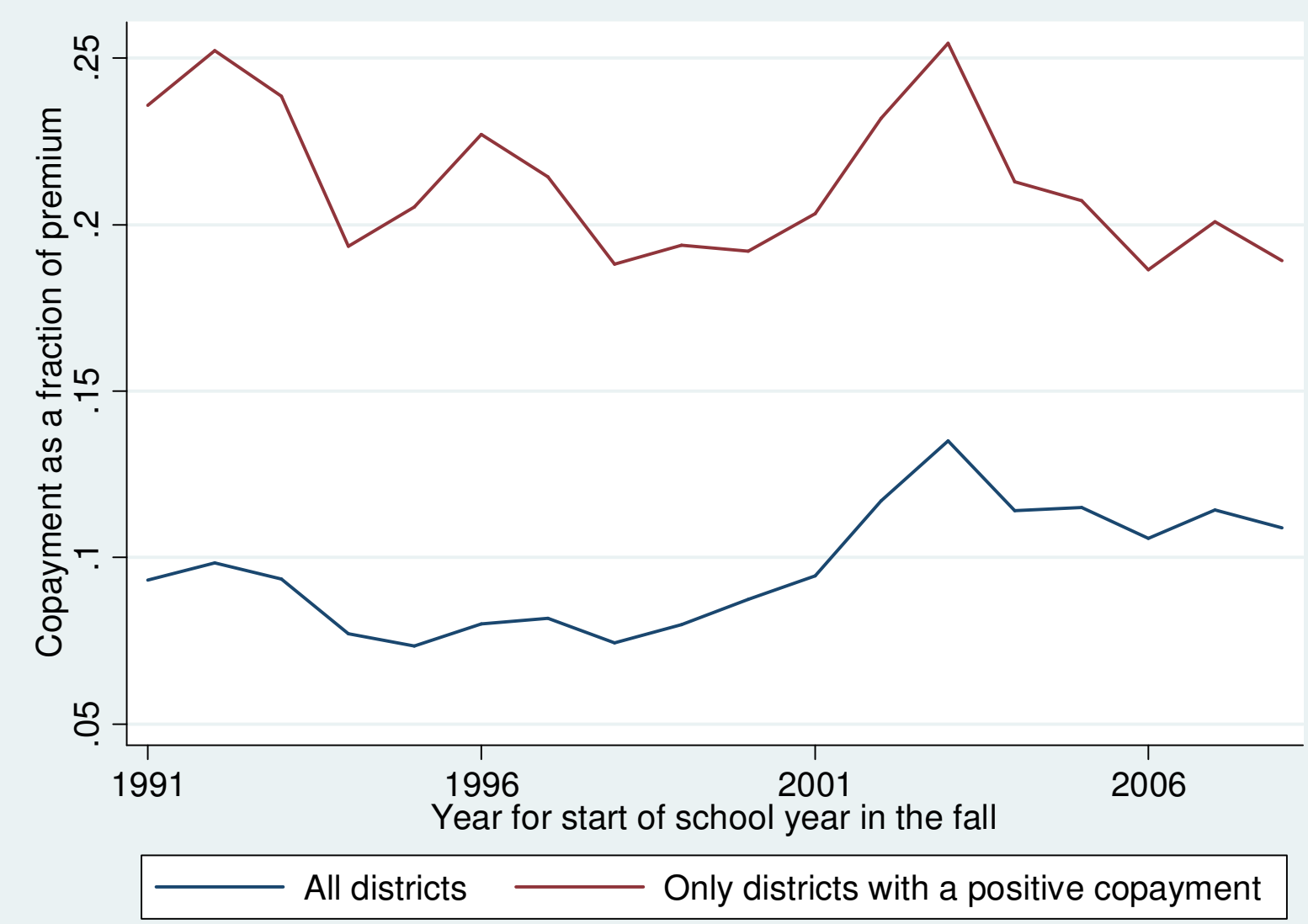


Figure 4b: Copayments for family insurance as a fraction of total premium, 1991-2008

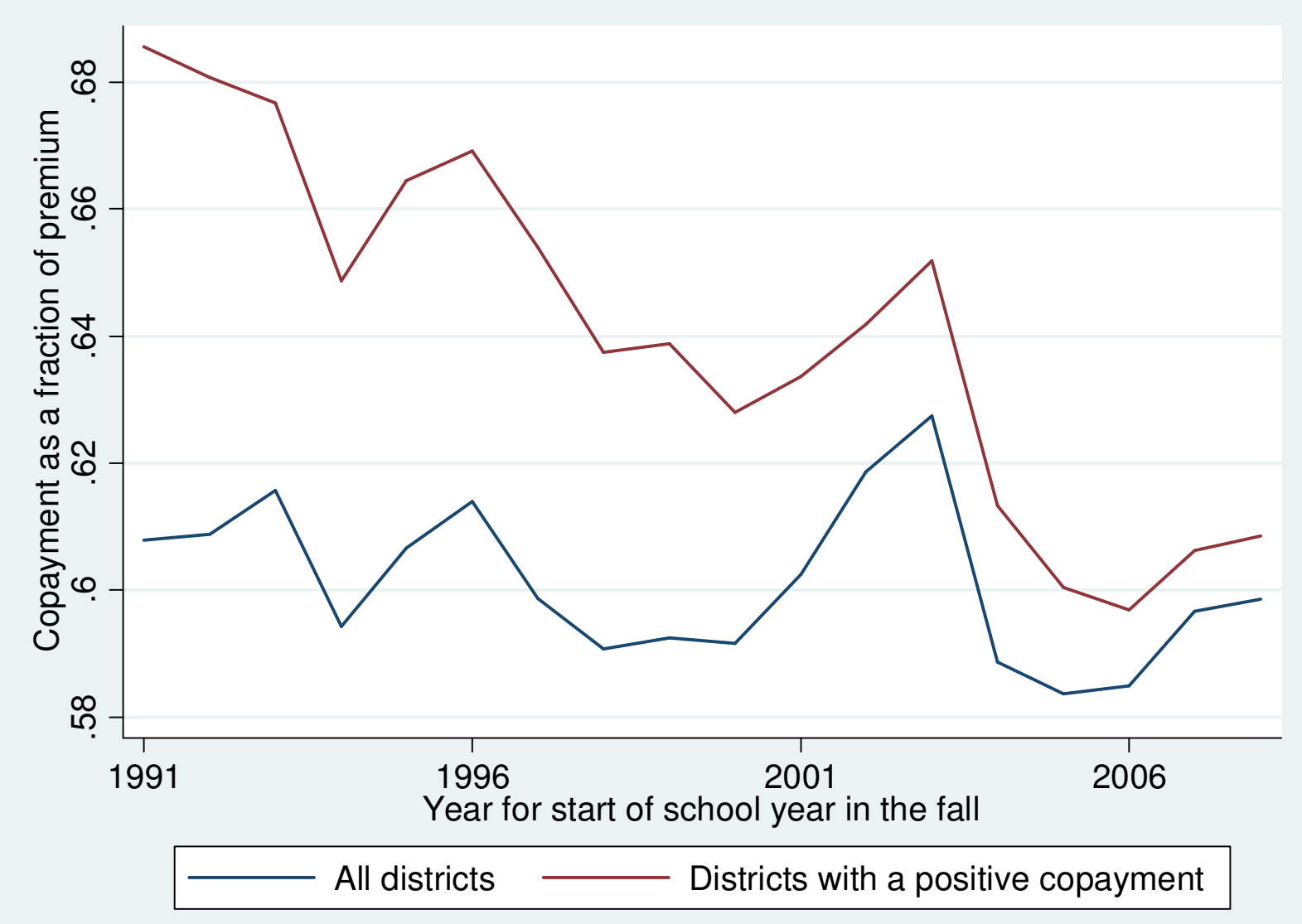


Figure 5: The cross-sectional relationship between individual health insurance premiums and salary, 2008

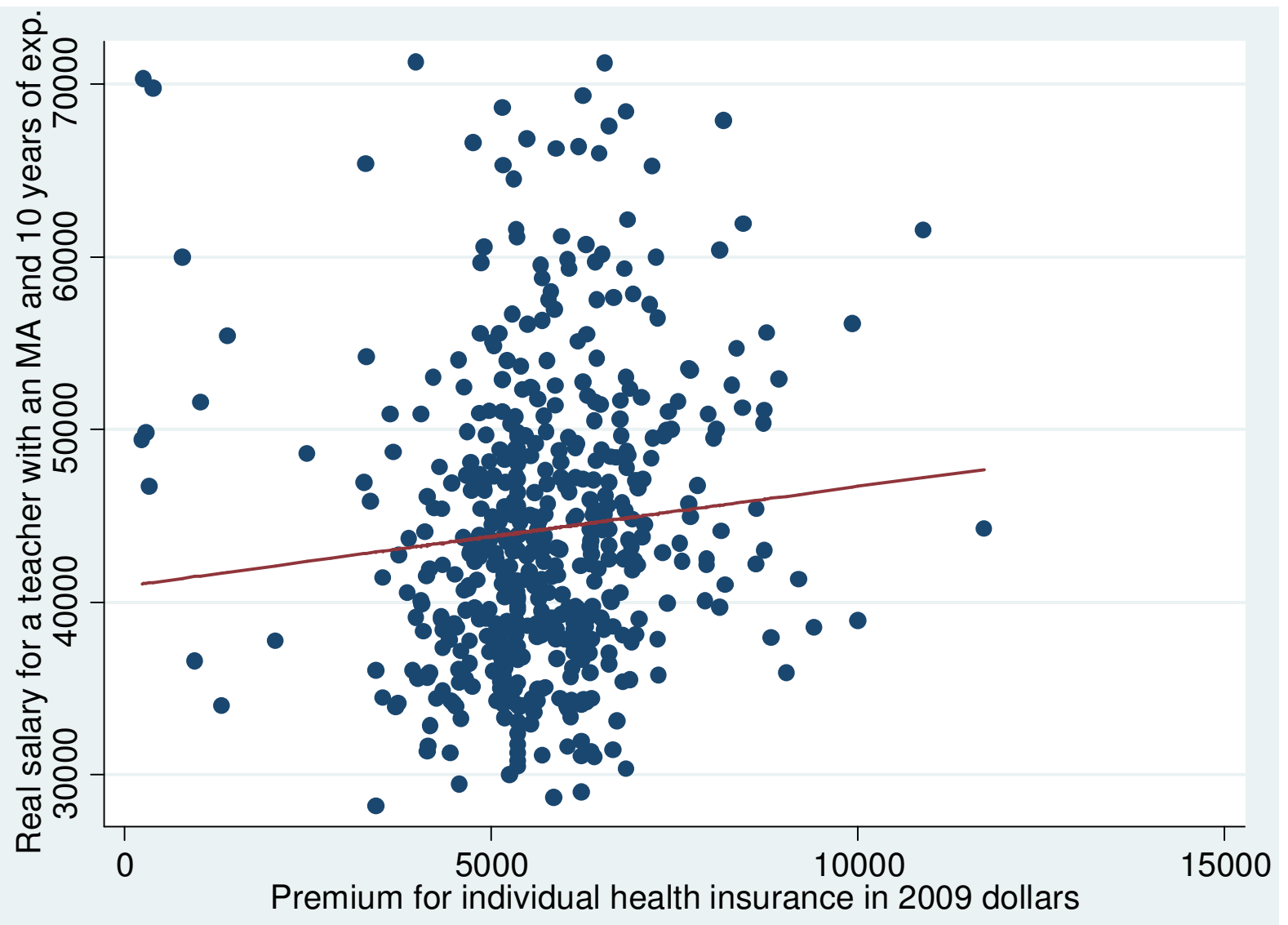


Figure 6: Changes in individual health insurance premiums and salary, 1999 to 2008

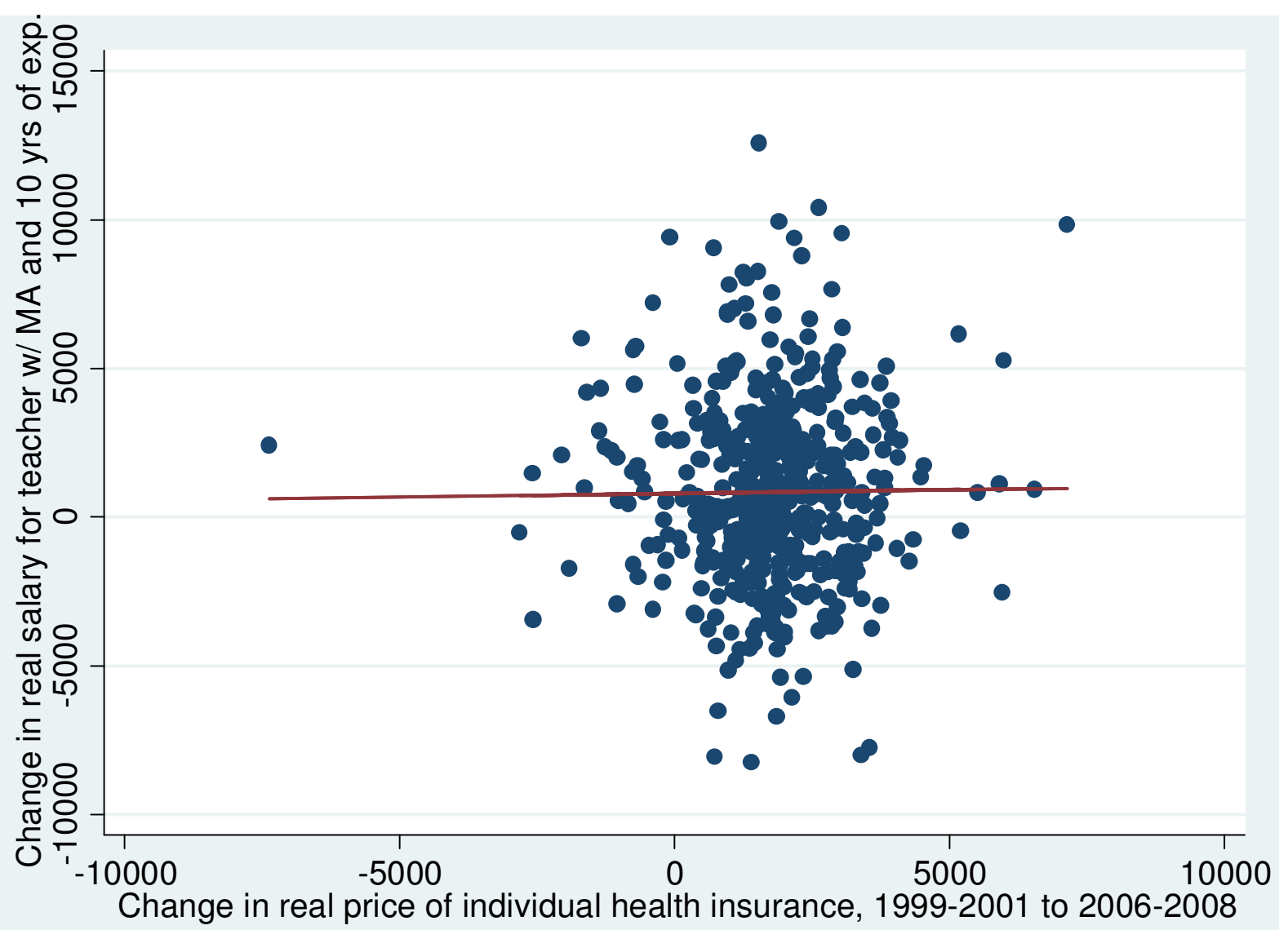


Figure 7: Changes in individual health insurance premiums and premium copayments, 1999 to 2008

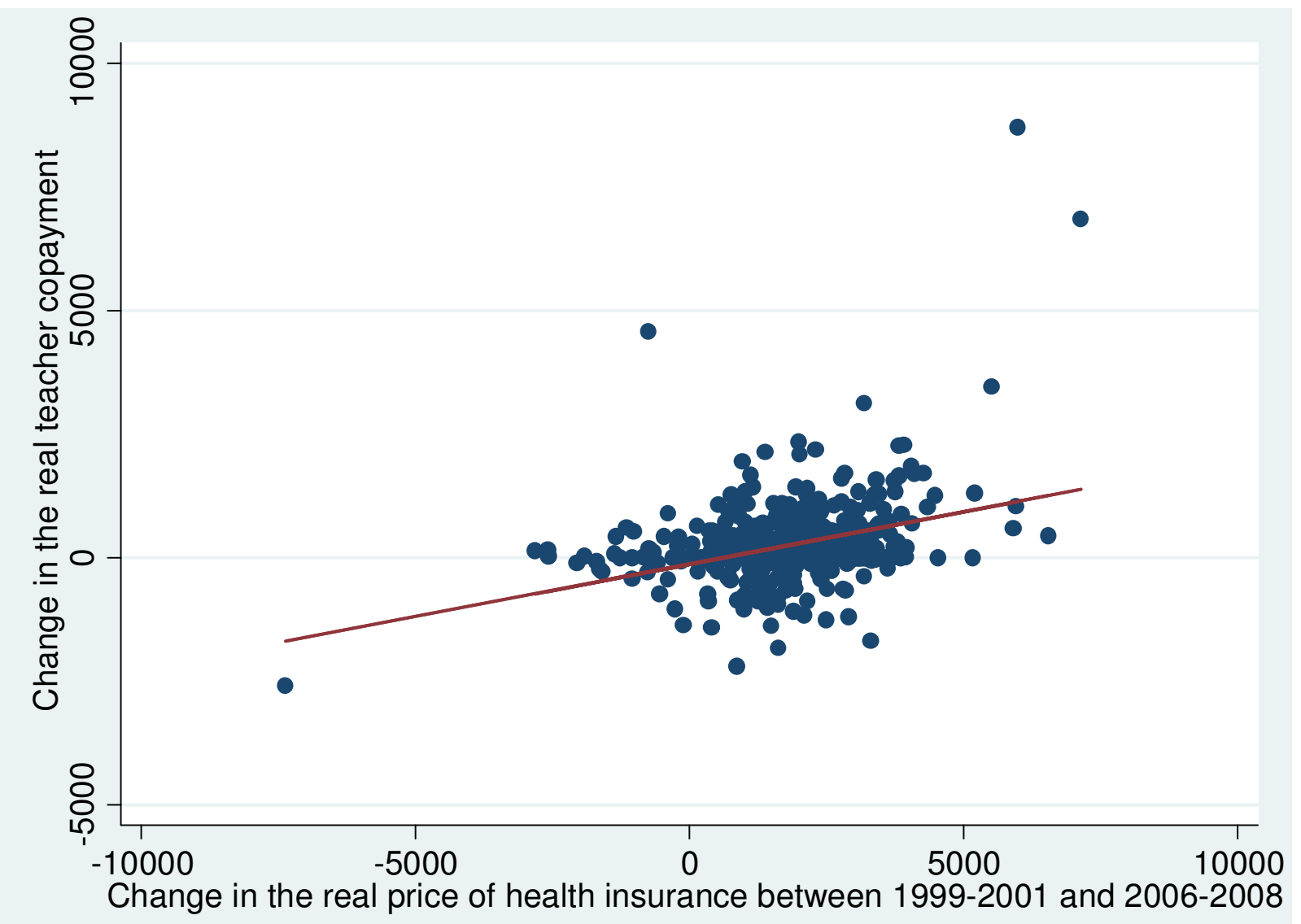




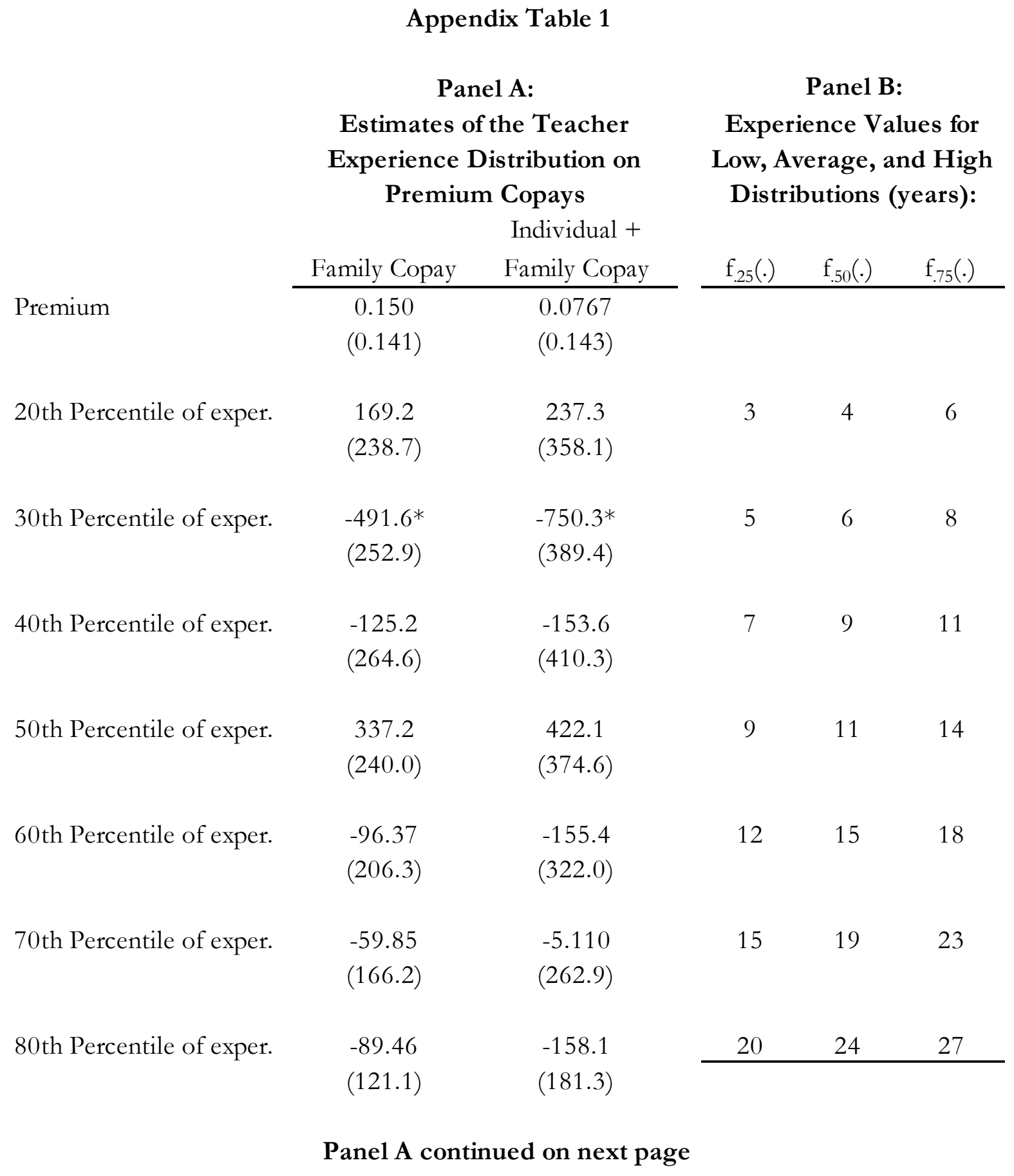




\section{Appendix Table 1, Panel A Continued}

\begin{tabular}{|c|c|c|}
\hline 20th percentile x Premium & $\begin{array}{l}-0.0217 \\
(0.0203)\end{array}$ & $\begin{array}{l}-0.0174 \\
(0.0209)\end{array}$ \\
\hline 30th percentile $x$ Premium & $\begin{array}{l}0.0584 * * \\
(0.0230)\end{array}$ & $\begin{array}{l}0.0551 * * \\
(0.0239)\end{array}$ \\
\hline 40th percentile $\mathrm{x}$ Premium & $\begin{array}{l}0.00542 \\
(0.0248)\end{array}$ & $\begin{array}{l}0.00376 \\
(0.0258)\end{array}$ \\
\hline 50th percentile $\mathrm{x}$ Premium & $\begin{array}{l}-0.0366^{*} \\
(0.0213)\end{array}$ & $\begin{array}{l}-0.0304 \\
(0.0226)\end{array}$ \\
\hline 60th percentile $x$ Premium & $\begin{array}{c}0.0214 \\
(0.0184)\end{array}$ & $\begin{array}{c}0.0200 \\
(0.0196)\end{array}$ \\
\hline 70th percentile $\mathrm{x}$ Premium & $\begin{array}{l}0.00478 \\
(0.0156)\end{array}$ & $\begin{array}{c}-0.000709 \\
(0.0166)\end{array}$ \\
\hline 80th percentile $x$ Premium & $\begin{array}{l}-0.000360 \\
(0.0106)\end{array}$ & $\begin{array}{l}0.00307 \\
(0.0109)\end{array}$ \\
\hline $\begin{array}{l}\text { P-value for joint significance } \\
\text { of interaction terms }\end{array}$ & 0.0092 & 0.0261 \\
\hline $\begin{array}{l}\text { P-value for joint significance } \\
\text { of exper and exper x prem } \\
\text { interaction terms }\end{array}$ & 0.0216 & 0.0544 \\
\hline Observations & 1056 & 1056 \\
\hline Number of Districts & 460 & 460 \\
\hline District fixed effects? & Yes & Yes \\
\hline
\end{tabular}

Notes: The premium measure in the first column is the additional cost to cover teachers' family members. The premium measure in the second column is the sum of the individual premium and the family premium. Standard errors in parentheses.

*** $\mathrm{p}<0.01,{ }^{* *} \mathrm{p}<0.05, * \mathrm{p}<0.1$ 